\title{
The summertime Boreal forest field measurement intensive (HUMPPA-COPEC-2010): an overview of meteorological and chemical influences
}

\author{
J. Williams ${ }^{1}$, J. Crowley ${ }^{1}$, H. Fischer ${ }^{1}$, H. Harder ${ }^{1}$, M. Martinez ${ }^{1}$, T. Petäjä ${ }^{2}$, J. Rinne ${ }^{2}$, J. Bäck ${ }^{3}$, M. Boy $^{2}$, \\ M. Dal Maso ${ }^{2}$, J. Hakala ${ }^{2}$, M. Kajos ${ }^{2}$, P. Keronen ${ }^{2}$, P. Rantala ${ }^{2}$, J. Aalto ${ }^{3}$, H. Aaltonen ${ }^{3,4}$, J. Paatero ${ }^{4}$, T. Vesala ${ }^{4}$, \\ H. Hakola ${ }^{2}$, J. Levula ${ }^{5}$, T. Pohja ${ }^{5}$, F. Herrmann ${ }^{1}$, J. Auld ${ }^{1}$, E. Mesarchaki ${ }^{1}$, W. Song ${ }^{1}$, N. Yassaa ${ }^{1,6}$, A. Nölscher ${ }^{1}$, \\ A. M. Johnson ${ }^{1, *}$, T. Custer ${ }^{1}$, V. Sinha ${ }^{1,{ }^{* *}}$, J. Thieser ${ }^{1}$, N. Pouvesle ${ }^{1}$, D. Taraborrelli ${ }^{1}$, M. J. Tang ${ }^{1}$, H. Bozem ${ }^{1}$, \\ Z. Hosaynali-Beygi ${ }^{1}$, R. Axinte ${ }^{1}$, R. Oswald ${ }^{1}$, A. Novelli ${ }^{1}$, D. Kubistin ${ }^{1}$, K. Hens ${ }^{1}$, U. Javed ${ }^{1}$, K. Trawny ${ }^{1}$, \\ C. Breitenberger ${ }^{1}$, P. J. Hidalgo ${ }^{7}$, C. J. Ebben ${ }^{8}$, F. M. Geiger ${ }^{8}$, A. L. Corrigan ${ }^{9}$, L. M. Russell ${ }^{9}$, H. G. Ouwersloot ${ }^{10}$, \\ J. Vilà-Guerau de Arellano ${ }^{10}$, L. Ganzeveld ${ }^{10}$, A. Vogel ${ }^{11}$, M. Beck ${ }^{11}$, A. Bayerle ${ }^{11}$, C. J. Kampf ${ }^{11}$, M. Bertelmann ${ }^{11}$, \\ F. Köllner ${ }^{11}$, T. Hoffmann ${ }^{11}$, J. Valverde ${ }^{12}$, D. González ${ }^{12}$, M.-L. Riekkola ${ }^{13}$, M. Kulmala ${ }^{2}$, and J. Lelieveld ${ }^{1}$ \\ ${ }^{1}$ Max Planck Institute for Chemistry, 55128 Mainz, Germany \\ ${ }^{2}$ Dept Phys, 00014 University of Helsinki, Finland \\ ${ }^{3}$ Dept. Forest Sciences, 00014 University of Helsinki, Helsinki, Finland \\ ${ }^{4}$ Finnish Meteorological Institute, Helsinki, Finland \\ ${ }^{5}$ Hyytiälä Forestry Field Station, 35500 Korkeakoski, Finland \\ ${ }^{6}$ University of Sciences and Technology Houari Boumediene (USTHB), Dept. Chemistry, 16111 Algiers, Algeria \\ ${ }^{7}$ University of Huelva, Department of Environmental Biology, 21071 Huelva, Spain \\ ${ }^{8}$ Northwestern University, Department of Chemistry, IL 60208, Evanston, USA \\ ${ }^{9}$ Scripps Institution of Oceanography, University of California San Diego, La Jolla CA 92093-0221, USA \\ ${ }^{10}$ Wageningen University, Department of Environmental Sciences, 6708 PB, Wageningen, The Netherlands \\ ${ }^{11}$ Johannes Gutenberg-University of Mainz, 55128 Mainz, Germany \\ ${ }^{12}$ School of Environmental Sciences, National University, Heredia, Costa Rica \\ ${ }^{13}$ Department of Chemistry, 00014 University of Helsinki, Helsinki, Finland \\ * now at: Indian Institute of Science Education and Research (IISER), Mohali, India \\ ** now at: Brigham Young University-Idaho, Department of Chemistry, ID 83460, USA
}

Received: 12 May 2011 - Published in Atmos. Chem. Phys. Discuss.: 26 May 2011

Revised: 5 September 2011 - Accepted: 3 October 2011 - Published: 27 October 2011

\begin{abstract}
This paper describes the background, instrumentation, goals, and the regional influences on the HUMPPACOPEC intensive field measurement campaign, conducted at the Boreal forest research station SMEAR II (Station for Measuring Ecosystem-Atmosphere Relation) in Hyytiälä, Finland from 12 July-12 August 2010. The prevailing meteorological conditions during the campaign are examined and contrasted with those of the past six years. Back trajectory analyses show that meteorological conditions at the site in 2010 were characterized by a higher proportion of southerly flow than in the other years studied. As a result the summer
\end{abstract}

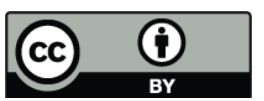

Correspondence to: J. Williams (jonathan.williams@mpic.de) of 2010 was anomalously warm and high in ozone making the campaign relevant for the analysis of possible future climates. A comprehensive land use analysis, provided on both 5 and $50 \mathrm{~km}$ scales, shows that the main vegetation types surrounding the site on both the regional and local scales are: coniferous forest (Scots pine and/or Norway spruce); mixed forest (Birch and conifers); and woodland scrub (e.g. Willows, Aspen); indicating that the campaign results can be taken as representative of the Boreal forest ecosystem. In addition to the influence of biogenic emissions, the measurement site was occasionally impacted by sources other than vegetation. Specific tracers have been used here to identify the time periods when such sources have impacted the site namely: biomass burning (acetonitrile and $\mathrm{CO}$ ), urban

Published by Copernicus Publications on behalf of the European Geosciences Union. 
anthropogenic pollution (pentane and $\mathrm{SO}_{2}$ ) and the nearby Korkeakoski sawmill (enantiomeric ratio of chiral monoterpenes). None of these sources dominated the study period, allowing the Boreal forest summertime emissions to be assessed and contrasted with various other source signatures.

\section{Introduction}

The Boreal forest ecosystem has a significant impact on the chemistry and physics of the Earth's atmosphere. Presently it covers approximately $15 \times 10^{6} \mathrm{~km}^{2}$ between 50 and $65^{\circ} \mathrm{N}$, some $8 \%$ of the Earth's land surface and $27 \%$ of the world's forest (FAO 2010). The Boreal forest contains some $10 \%$ of the total carbon in the terrestrial ecosystem and has no parallel in the Southern Hemisphere due to the absence of landmass in the corresponding southerly latitude band. The vegetation of the Boreal forest comprises mainly wind pollinated pine and spruce trees (Gymnosperms - e.g. Pinus sylvestris, Picea abies, and Angiosperms - e.g. Betula sp, Alnus incana, Populus tremula) with low biodiversity in comparison to other forested areas such as tropical forests. These coniferous trees are known to emit significant quantities of reactive organic trace gases (e.g. monoterpenes) to the atmosphere as a function of temperature and to a lesser extent light (Rinne et al., 2009 and references therein). Rapid atmospheric oxidation of these biogenic trace gases and subsequent gas to particle conversion, have been shown to sustain particle concentrations of 1000-2000 particles $/ \mathrm{cm}^{3}$ in the climatically relevant size range of 40-100 nm (Tunved et al., 2006, Kulmala et al., 2004). Previous studies from Boreal forest sites have indicated that some $12-50 \%$ of aerosol mass and $50 \%$ of cloud condensation nuclei $(\mathrm{CCN})$ originates from forest sources (Tunved et al., 2008; Sihto et al., 2010) and that particle formation over the Finnish boreal forest causes a local radiative perturbation of between -5 and $-14 \mathrm{Wm}^{-2}$ (global mean -0.03 to $-1.1 \mathrm{Wm}^{-2}$ ) (Kurten et al., 2003). It has been suggested that these cooling effects can offset the snowvegetation albedo effect of the forest (Spracklen et al., 2008).

The enormous extent of the Boreal forest means that reactive organic emissions from such regions have the potential to reduce the Earth's oxidation capacity (by the regional depletion of key oxidants $\mathrm{OH}$ and $\mathrm{O}_{3}$ ), and alter the Earth's radiative budget by particle formation and subsequent scattering, absorption or reflection of light (either directly or via the role of aerosol particles as cloud condensation nuclei). Yet our understanding of atmospheric chemistry of the Boreal forest remains incomplete in key areas, in particular with regard to: the emission rate and speciation of volatile organic compounds; the extent of $\mathrm{OH}$ recycling during the oxidation process (e.g. Lelieveld et al., 2008), and in the precise formation and growth mechanisms of secondary organic aerosol, SOA (e.g. Kulmala et al., 2004; Kulmala and Kerminen, 2008). Indeed recent global SOA budgets, to which the Boreal for- est is a major contributor, differ by an order of magnitude (Kanakidou et al., 2005; Goldstein and Galbally, 2007; Hallquist et al., 2009). In future the Earth is predicted to warm, and Boreal regions more than any other $\left(2-10^{\circ} \mathrm{C}\right)$ by 2100 (IPCC 2006). In order to predict the future impact of the Boreal forest on the atmosphere, and thereby to improve assessment of potential climatic feedbacks (e.g. Carslaw et al., 2010), extensive, high quality, and comprehensive datasets must be generated for detailed analysis. In this regard summertime assessments are particularly useful.

This paper provides an overview of the Boreal forest field measurement intensive HUMPPA-COPEC 2010 (Hyytiälä United Measurement of Photochemistry and Particles Comprehensive Organic Particle and Environmental Chemistry). The measurements took place at the Boreal forest field station in Hyytiälä, Finland (Latitude $61^{\circ} 51^{\prime} \mathrm{N}$; Longitude $24^{\circ} 17^{\prime} \mathrm{E}$, elevation $181 \mathrm{~m}$ a.s.l., see Fig. 1) from 12 July-12 August 2010. To date, most intensive measurement campaigns performed at this station have been made in spring or autumn, to coincide with periods of most frequent particle nucleation events. In contrast, HUMPPA-COPEC 2010 was focused on characterizing summertime conditions when emission fluxes of volatile organic compounds (VOC), $\mathrm{OH}$ initiated photochemistry, and particle growth rates reach their seasonal maximum. In the course of the campaign, an international consortium quantified a comprehensive suite of gas and particle phase species (see Table 1). This was the largest campaign staged in the 100 year history of the Hyytiälä forestry station and this paper provides an overview of the campaign objectives, the instrumentation deployed, a site description, a regional vegetation analysis, a meteorological analysis, and an assessment of the main emission sources impacting the site.

\section{Objectives}

The general objective of the HUMPPA-COPEC 2010 campaign was to comprehensively characterize the atmospheric physics and chemistry over a Boreal forest site in summer. The more specific objectives are summarized below. Detailed analyses addressing these goals are provided in the accompanying papers of this special issue.

\subsection{Volatile organic compound characterization}

The first objective of the HUMPPA-COPEC 2010 campaign was to comprehensively characterize the fluxes, concentration ranges, and composition of VOCs emitted from the Boreal forest in summer. Earlier studies of specific monoterpenes at the Hyytiälä site have determined distinct seasonal variations in VOC concentration, with much higher levels in summer (Hakola et al., 2003). Boreal forest VOC emissions occur in numerous highly reactive, reduced forms such as isoprene $\left(\mathrm{C}_{5} \mathrm{H}_{8}\right)$, monoterpenes $\left(\mathrm{C}_{10} \mathrm{H}_{16}\right)$, 


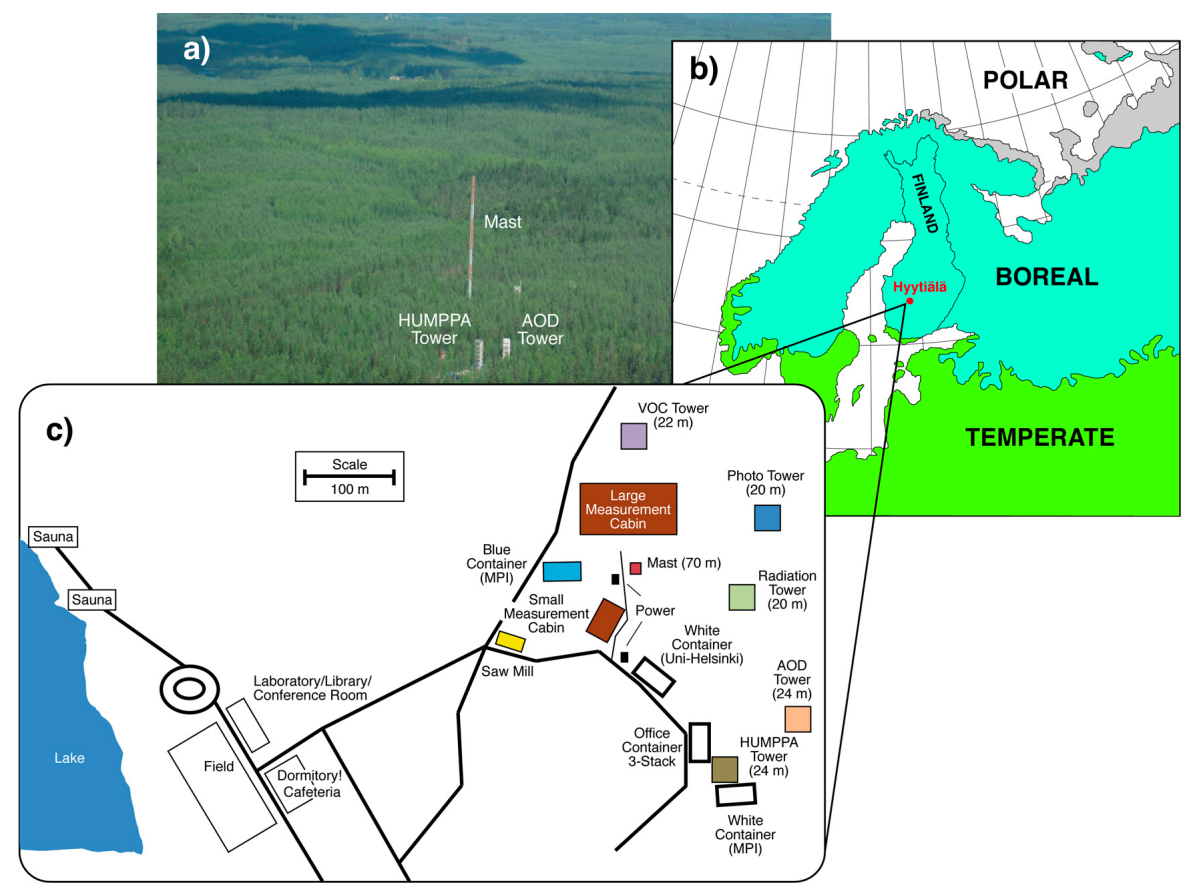

Fig. 1. This Fig. is a composite of (a) an aerial view taken during the campaign of the Hyytiälä site looking northwest, (b) a map of the bioclimatically defined Boreal region of Europe, and (c) a local map of the site showing locations of instruments and towers (see also Table 1).

and sesquiterpenes $\left(\mathrm{C}_{15} \mathrm{H}_{24}\right)$ (Tarvainen et al., 2005; Hakola et al., 2006; Aaltonen et al., 2011). Additional nonterpenoid emissions or photochemical products (e.g. oxygenated VOCs) are generally less well characterized (Rinne et al., 2009), although some have been quantified at the Hyytiälä site (Janson et al., 1999; Janson and Serves, 2001; Rinne et al., 2007). One aim of the HUMPPA-COPEC campaign was to improve speciation of VOCs by applying new techniques (e.g. SPME - solid phase micro extraction) and more instrumentation than has been deployed before (see, Table 1). The main focus was on ambient air VOC measurements, which were made both within, and at various heights above the canopy to provide both a spatial and temporal assessment. In addition to individual VOCs, measurements of total $\mathrm{OH}$ reactivity were made by the comparative reactivity method (Sinha et al., 2008, 2010) in order to assess the extent to which VOCs are being quantified by the methods applied. Results are presented by Nölscher et al., 2011a within this special issue and these show average summer daytime $\mathrm{OH}$ reactivities to be ca. $12 \mathrm{~s}^{-1}$ with significant fractions $(\sim 40 \%)$ unassigned. Furthermore, two alternative instruments for measuring reactivity (Proton Transfer Reaction Mass Spectrometer, PTR-MS and Gas Chromatography with Photo Ionization Detector, GC-PID) were compared during the campaign (Nölscher et al., 2011b). Branch cuvettes were employed to speciate and quantify the VOC emissions from selected tree chemotypes. This was particularly important for the determination of very reactive compounds (e.g., alpha- terpinene, beta-myrcene) or sesquiterpenes which react with ozone on the order of seconds and are thus difficult to quantify in ambient air.

Continuous, on-line measurements of monoterpenes and oxygenated VOCs from dynamic branch and soil enclosures were conducted with PTR-MS. The comprehensive measurement system at SMEAR II enables comparison with other tree physiological parameters, such as photosynthesis and transpiration, and analyzing connections between the physiological status of plant and its VOC emissions. The on-line measurements from soil enclosures provide information on additional sources for VOCs from biotic or abiotic soil processes.

\subsection{Radical chemistry and recycling}

Many of the VOCs emitted from the Boreal forest can react rapidly with atmospheric oxidants $\left(\mathrm{OH}, \mathrm{O}_{3}, \mathrm{NO}_{3}\right)$. Determining which oxidizing species was most important for initiating reactions with Boreal forest VOC, and the extent of any chemical recycling was the second objective of this campaign. Recent field studies in tropical rainforest regions (Lelieveld et al., 2008; Hewitt et al., 2010) have indicated that the primary atmospheric oxidant $(\mathrm{OH})$ is not simply consumed by reaction with VOCs but rather recycled to some degree. Plausible $\mathrm{OH}$ recycling mechanisms have also been derived from theoretical and laboratory studies of the molecule isoprene (Peeters et al., 2009; Paulot et al., 2009). This recycling is thought to be important in maintaining the 
Table 1. The measurements made during the HUMPPA-COPEC intensive are tabulated alongside, the instrument type, time resolution, detection limit, responsible institute and location of the inlet (see also Fig. 1).

\begin{tabular}{|c|c|c|c|c|c|}
\hline $\begin{array}{l}\text { Gas Phase } \\
\text { Measurement }\end{array}$ & Time resolution & Detection Limit* & Technique & Institution & Inlet Location (Fig. 1) \\
\hline $\begin{array}{l}\mathrm{m} 28, \mathrm{~m} 31, \mathrm{~m} 33, \mathrm{~m} 45, \mathrm{~m} 59 \\
\mathrm{~m} 69, \mathrm{~m} 71, \mathrm{~m} 79, \mathrm{~m} 93\end{array}$ & $5 \min$ & $\sim 50 \mathrm{ppt}$ & $\begin{array}{l}\text { PTR-MS with cold } \\
\text { trap }\end{array}$ & MPI & $\begin{array}{l}\text { HUMPPA tower } \\
(24 \mathrm{~m})\end{array}$ \\
\hline Total reactivity to $\mathrm{OH}$ & $1 \mathrm{~min}$ & $3 \mathrm{~s}-1$ & $\begin{array}{l}\text { Reactivity (PTR- } \\
\text { MS) }\end{array}$ & MPI & $\begin{array}{l}\text { HUMPPA tower } \\
(24 \mathrm{~m} \& 18 \mathrm{~m})\end{array}$ \\
\hline Total reactivity to $\mathrm{OH}$ & $2 \min$ & $3 \mathrm{~s}-1$ & $\begin{array}{l}\text { Reactivity (GC- } \\
\text { PID) }\end{array}$ & MPI & $\begin{array}{l}\text { HUMPPA tower } \\
(24 \mathrm{~m} \& 18 \mathrm{~m})\end{array}$ \\
\hline $\begin{array}{l}\text { Chiral monoterpenes } \\
+ \text { isoprene }\end{array}$ & $60 \mathrm{~min}$ & $1 \mathrm{ppt}$ & GC-MS & MPI & HUMPPA tower (24 m) \\
\hline $\begin{array}{l}\text { Chiral emissions } \\
\text { C10H16 \& C15H24 }\end{array}$ & $60 \mathrm{~min}$ & $1 \mathrm{ppt}$ & $\begin{array}{l}\text { Cuvette - SPME - } \\
\text { GC-MS }\end{array}$ & MPI & VOC tower $(16 \mathrm{~m})$ \\
\hline Alkanes and alkenes & $5.5 \mathrm{~min}$ & $\sim 1 \mathrm{ppt}$ & GC-MS & MPI & Mast (16 m/4 m) \\
\hline Methane & $70 \mathrm{~s}$ & $0.01 \mathrm{ppm}$ & GC-FID & MPI & Mast (4 m) \\
\hline Speciated PANs & $3.5 \mathrm{~s}$ & $30 \mathrm{ppt}^{\mathrm{a}}$ & CIMS & MPI & HUMPPA tower (24 m) \\
\hline $\mathrm{NO}_{3}$ & $5 \mathrm{~s}$ & $2-4 p p t^{b}$ & CRD & MPI & HUMPPA tower (24 m) \\
\hline $\mathrm{N}_{2} \mathrm{O}_{5}$ & $5 \mathrm{~s}$ & $5-10 \mathrm{ppt}^{\mathrm{b}}$ & CRD & MPI & HUMPPA tower (24 m) \\
\hline $\mathrm{NO}_{2}$ & $5 \mathrm{~s}$ & $20-100 \mathrm{ppt}^{\mathrm{b}}$ & CRD & MPI & HUMPPA tower (24 m) \\
\hline$\Sigma$ PANs & $4 \mathrm{~s}$ & $50-100 \mathrm{ppt}^{\mathrm{b}}$ & CRD & MPI & HUMPPA tower (24 m) \\
\hline $\mathrm{OH}$ and $\mathrm{HO}_{2}$ & & & $\mathrm{LiF}$ & MPI & $\begin{array}{l}\text { White container } \\
\text { (UH) \& HUMPPA tower } \\
(24 \mathrm{~m})\end{array}$ \\
\hline $\mathrm{NO}_{2}$ & & & & MPI & $\begin{array}{l}\text { White container } \\
\text { (UH) \& HUMPPA tower } \\
(24 \mathrm{~m})\end{array}$ \\
\hline $\mathrm{NO}, \mathrm{NO}_{2}$ & & & CLD & MPI & HUMPPA tower (24 m) \\
\hline $\mathrm{O}_{3}$ & $3 \mathrm{~s}$ & $\sim 1 \mathrm{ppb}$ & UV & MPI & HUMPPA tower (24 m) \\
\hline $\mathrm{CO}$ & $1 \mathrm{~s}$ & $\sim 1 \mathrm{ppb}$ & UV & MPI & HUMPPA tower (24 m) \\
\hline $\mathrm{CH}_{2} \mathrm{O}$ & & & Hantzch & MPI & HUMPPA tower (24 m) \\
\hline $\begin{array}{l}\mathrm{H}_{2} \mathrm{O}_{2} \text { and Organic } \\
\text { Peroxides }\end{array}$ & & & Dual enzyme & MPI & HUMPPA tower (24 m) \\
\hline$J \mathrm{NO}_{2}, J \mathrm{O}_{1} \mathrm{D}$ & & & Radiometer & MPI & HUMPPA tower (24 m) \\
\hline Speciated peroxides & & & LC-MS & NUCR/MPI & HUMPPA tower (24 m) \\
\hline HONO (tower) & & & LOPAP & MPI & HUMPPA tower (24 m) \\
\hline HONO (forest floor) & & & LOPAP & MPI & Ground - Forest floor \\
\hline Total carbon & & & Oven - Licorr & MPI & HUMPPA tower (24 m) \\
\hline terpenes & $30 \mathrm{~min}$ & $\sim 10 \mathrm{ppt}$ & Cartridge - GC-MS & MPI & HUMPPA tower (24 m) \\
\hline $\mathrm{CO}_{2}$ & $6 \min$ & $\pm 3 \mathrm{ppmv}$ & $\mathrm{IRGA}^{\mathrm{c}}$ & UH & $\begin{array}{l}\text { Mast }(4.2,8.4,16.8,33.6 \text {, } \\
50.4,67.2 \mathrm{~m})\end{array}$ \\
\hline $\mathrm{H}_{2} \mathrm{SO}_{4}$ & $30 \mathrm{~s}$ & $5 \times 10^{4} \mathrm{~cm}^{-3}$ & CIMS & UH & White container UH \\
\hline $\mathrm{OH}$ & $30 \mathrm{~s}$ & $5 \times 10^{4} \mathrm{~cm}^{-3}$ & CIMS & $\mathrm{UH}$ & White container UH \\
\hline
\end{tabular}

oxidation efficiency over the tropical rainforest where isoprene emissions dominate. However, over the Boreal forest where isoprene emissions are low and monoterpenes more abundant than isoprene, the recycling efficiency remains unknown. Simultaneous measurements of $\mathrm{OH}$ production from the photolysis rates $J_{\mathrm{O} 1} \mathrm{D}, J_{\mathrm{HCHO}}$, and $J_{\mathrm{HONO}}$, in situ $\mathrm{OH}$, 
Table 1. Continued.

\begin{tabular}{|c|c|c|c|c|c|}
\hline $\begin{array}{l}\text { Gas Phase } \\
\text { Measurement }\end{array}$ & Time resolution & Detection Limit* & Technique & Institution & Inlet Location (Fig. 1) \\
\hline $\begin{array}{l}\mathrm{m} 31, \mathrm{~m} 33, \mathrm{~m} 42, \mathrm{~m} 45, \mathrm{~m} 47, \\
\mathrm{~m} 59, \mathrm{~m} 61, \mathrm{~m} 69, \mathrm{~m} 71, \mathrm{~m} 73, \\
\mathrm{~m} 79, \mathrm{~m} 81, \mathrm{~m} 83, \mathrm{~m} 85, \mathrm{~m} 87, \\
\mathrm{~m} 93, \mathrm{~m} 99, \mathrm{~m} 101, \mathrm{~m} 103, \\
\mathrm{~m} 113, \mathrm{~m} 137, \mathrm{~m} 141, \mathrm{~m} 153, \\
\mathrm{~m} 155, \mathrm{~m} 169, \mathrm{~m} 205, \mathrm{~m} 263\end{array}$ & $6 \mathrm{~min}$ & $\sim 50 \mathrm{ppt}$ & PTR-MS Profile & $\mathrm{UH}$ & $\begin{array}{l}\text { Mast }(4.2,8.4,16.8,33.6 \text {, } \\
50.4,67.2 \mathrm{~m})\end{array}$ \\
\hline Total reactivity & $\begin{array}{l}\text { data very lim- } \\
\text { ited }\end{array}$ & & $\begin{array}{l}\text { PTR-MS } \\
\text { Reactivity }\end{array}$ & $\mathrm{UH}$ & Cuvette near sawmill \\
\hline $\begin{array}{l}\mathrm{m} 31, \mathrm{~m} 33, \mathrm{~m} 37, \mathrm{~m} 45, \\
\mathrm{~m} 59, \mathrm{~m} 69, \mathrm{~m} 81, \mathrm{~m} 87, \mathrm{~m} 99, \\
\mathrm{~m} 101, \mathrm{~m} 113, \mathrm{~m} 137\end{array}$ & $\sim 10 \mathrm{~s}$ & $\sim 50 \mathrm{ppt}$ & PTR-MS Flux & $\mathrm{UH}$ & Radiation tower $(20 \mathrm{~m})$ \\
\hline mono- and sesquiterpenes & $\begin{array}{l}\text { data very lim- } \\
\text { ited }\end{array}$ & & GC-MS & FMI & Cuvette near sawmill \\
\hline $\begin{array}{l}\mathrm{HCl}, \mathrm{HNO}_{3}, \mathrm{HNO}_{2}, \mathrm{SO}_{2}, \\
\mathrm{NH}_{3}\end{array}$ & $60 \mathrm{~min}$ & $0.005-0.01 \mu \mathrm{g} \mathrm{m}^{-3}$ & MARGA & FMI & $\begin{array}{l}\text { Cabin }(2.5 \mathrm{~m}) \text {, close to } \\
\text { sawmill }\end{array}$ \\
\hline Organic amines & 2-3 days & & $\begin{array}{l}\text { Impregnated filter- } \\
\text { LC-MS }\end{array}$ & FMI & container near sawmill \\
\hline $\mathrm{H}_{2} \mathrm{O}$ & $6 \mathrm{~min}$ & $\pm 0.3 \mathrm{ppthv}$ & IRGA $^{\mathrm{c}}$ & $\mathrm{UH}$ & $\begin{array}{l}\text { Mast }(4.2,8.4,16.8,33.6 \text {, } \\
50.4,67.2 \mathrm{~m})\end{array}$ \\
\hline $\mathrm{SO}_{2}$ & $6 \mathrm{~min}$ & $0.1 \mathrm{ppb}$ & UV & $\mathrm{UH}$ & $\begin{array}{l}\text { Mast }(4.2,8.4,16.8,33.6 \text {, } \\
50.4,67.2 \mathrm{~m})\end{array}$ \\
\hline $\mathrm{O}_{3}$ & $6 \min$ & $1 \mathrm{ppb}$ & UV & $\mathrm{UH}$ & $\begin{array}{l}\text { Mast }(4.2,8.4,16.8,33.6 \text {, } \\
50.4,67.2 \mathrm{~m})\end{array}$ \\
\hline NO & $6 \mathrm{~min}$ & $0.1 \mathrm{ppb}$ & CLD & $\mathrm{UH}$ & $\begin{array}{l}\text { Mast }(4.2,8.4,16.8,33.6 \text {, } \\
50.4,67.2 \mathrm{~m})\end{array}$ \\
\hline $\mathrm{NO}_{\mathrm{x}}$ & $6 \mathrm{~min}$ & $0.1 \mathrm{ppb}$ & CLD & $\mathrm{UH}$ & $\begin{array}{l}\text { Mast }(4.2,8.4,16.8,33.6 \text {, } \\
50.4,67.2 \mathrm{~m})\end{array}$ \\
\hline $\mathrm{CO}$ & $6 \mathrm{~min}$ & $20 \mathrm{ppb}$ & IRGA & $\mathrm{UH}$ & $\begin{array}{l}\text { Mast }(4.2,8.4,16.8,33.6 \text {, } \\
50.4,67.2 \mathrm{~m})\end{array}$ \\
\hline $\mathrm{O}_{3}$ flux & $30 \mathrm{~min}$ & & $\begin{array}{l}\text { Eddy covariance - } \\
\text { CLD }\end{array}$ & $\mathrm{UH}$ & Radiation tower $(23 \mathrm{~m})$ \\
\hline $\mathrm{CO}_{2}$ flux & $30 \mathrm{~min}$ & & $\begin{array}{l}\text { Eddy covariance - } \\
\text { IRGA }\end{array}$ & $\mathrm{UH}$ & Mast (23 m) \\
\hline $\mathrm{H}_{2} \mathrm{O}$ flux & $30 \mathrm{~min}$ & & $\begin{array}{l}\text { Eddy covariance - } \\
\text { IRGA }\end{array}$ & $\mathrm{UH}$ & Mast (23 m) \\
\hline $\begin{array}{l}\mathrm{CO}_{2} \text { flux pine } \\
\text { branches \& aspen leaves, } \\
\text { pine stem, soil }\end{array}$ & $\begin{array}{l}\text { Variable } \\
(15 \min . . .3 \mathrm{~h})\end{array}$ & & Cuvette - IRGA & $\mathrm{UH}$ & Photo-tower (16 m) \\
\hline $\begin{array}{l}\mathrm{H}_{2} \mathrm{O} \text { flux pine } \\
\text { branches \& aspen leaves, } \\
\text { soil }\end{array}$ & $\begin{array}{l}\text { Variable } \\
(15 \min . . .3 \mathrm{~h})\end{array}$ & & Cuvette - IRGA & $\mathrm{UH}$ & Photo-tower (16 m) \\
\hline Aerosol particle mass & 3 days & $\mathrm{PM}_{10}, \mathrm{PM}_{2.5}, \mathrm{PM}_{1}$ & $\begin{array}{l}\text { Dekati cascade im- } \\
\text { pactor }\end{array}$ & $\mathrm{UH}$ & Aerosol cottage \\
\hline $\begin{array}{l}\mathrm{O}_{3} \text { flux, pine } \\
\text { branches \& aspen leaves }\end{array}$ & $\begin{array}{l}\text { Variable } \\
(15 \mathrm{~min} . . .3 \mathrm{~h})\end{array}$ & & Cuvette - UV & $\mathrm{UH}$ & Photo-tower (16 m) \\
\hline
\end{tabular}

and $\mathrm{OH}$ reactivity (the total $\mathrm{OH}$ sink) were made to examine the budget. Whilst $\mathrm{OH}$ is generally considered to be the dominant oxidant of many VOCs during the day, $\mathrm{NO}_{3}$ and $\mathrm{O}_{3}$ persist through the night when they contribute substan- tially to, or even dominate VOC removal. For comparison, $\mathrm{NO}_{3}$, and $\mathrm{O}_{3}$ measurements were made at the same location (see Fig. 1 and Table 1). 
Table 1. Continued.

\begin{tabular}{|c|c|c|c|c|c|}
\hline $\begin{array}{l}\text { Gas Phase } \\
\text { Measurement }\end{array}$ & Time resolution & Detection Limit* & Technique & Institution & Inlet Location (Fig. 1) \\
\hline $\begin{array}{l}\text { NO flux, pine } \\
\text { branches \& aspen leaves }\end{array}$ & $\begin{array}{l}\text { Variable } \\
(15 \min \ldots . .3 \mathrm{~h})\end{array}$ & & Cuvette - CLD & $\mathrm{UH}$ & Photo-tower (16 m) \\
\hline $\begin{array}{l}\mathrm{NO}_{\mathrm{x}} \text { flux, pine } \\
\text { branches \& aspen leaves }\end{array}$ & $\begin{array}{l}\text { Variable } \\
(15 \mathrm{~min} . . .3 \mathrm{~h})\end{array}$ & & Cuvette - CLD & $\mathrm{UH}$ & Photo-tower (16 m) \\
\hline $\begin{array}{l}\mathrm{m} 33, \mathrm{~m} 45, \quad \mathrm{~m} 59, \quad \mathrm{~m} 69, \\
\mathrm{~m} 79, \mathrm{~m} 81, \mathrm{~m} 99, \quad \mathrm{~m} 101, \\
\mathrm{~m} 137, \mathrm{~m} 153 \text { flux (pine } \\
\text { branches \& aspen leaves) }\end{array}$ & $\begin{array}{l}\text { Variable } \\
(15 \mathrm{~min} . . .3 \mathrm{~h})\end{array}$ & $\sim 50 \mathrm{ppt}$ & Cuvette - PTR-MS & $\mathrm{UH}$ & Photo-tower (16 m) \\
\hline $\begin{array}{l}\mathrm{m} 33, \mathrm{~m} 45, \mathrm{~m} 59, \mathrm{~m} 69, \mathrm{~m} 79 \\
\mathrm{~m} 81, \mathrm{~m} 99, \mathrm{~m} 101, \mathrm{~m} 137, \\
\mathrm{~m} 153 \text { flux (soil) }\end{array}$ & $\begin{array}{l}\text { Variable } \\
(15 \mathrm{~min} . . .3 \mathrm{~h})\end{array}$ & $\sim 50 \mathrm{ppt}$ & Cuvette - PTR-MS & $\mathrm{UH}$ & watershed, ground \\
\hline $\begin{array}{l}\text { mono \& sesquiterpenes } \\
\text { (herbivores; pine branches) }\end{array}$ & $2-3$ times & $10-80 \mathrm{ng} \mathrm{m}^{-3}$ & $\begin{array}{l}\text { Cuvette - Tenax - } \\
\text { GC-MS }\end{array}$ & $\mathrm{UH}$ & VOC tower $(16 \mathrm{~m})$ \\
\hline Aerosol Phase & & & & & \\
\hline Measurement & Time resolution & $\begin{array}{l}\text { Detection } \\
\text { Limit/size limit }\end{array}$ & Technique & Institution & Inlet Location \\
\hline $\begin{array}{l}\text { Total particle number con- } \\
\text { centration }\end{array}$ & $1 \mathrm{~min}$ & $10 \mathrm{~nm}$ & CPC 3022 & $\mathrm{UH}$ & Aerosol cottage \\
\hline $\begin{array}{l}\text { Aerosol number size distri- } \\
\text { bution }\end{array}$ & $10 \mathrm{~min}$ & $3-1000 \mathrm{~nm}$ & Twin-DMPS & $\mathrm{UH}$ & Aerosol cottage \\
\hline $\begin{array}{l}\text { Aerosol number size distri- } \\
\text { bution }\end{array}$ & $10 \mathrm{~min}$ & $0.5-10 \mu \mathrm{m}$ & TSI-3320 APS & $\mathrm{UH}$ & Aerosol cottage \\
\hline $\begin{array}{l}\text { Particle } \\
\text { concentration }+ \text { size info }\end{array}$ & $30 \mathrm{~s}$ & $1.5 \mathrm{~nm}$ & PH-CPC & UH & Aerosol cottage \\
\hline $\begin{array}{l}\text { Total particle concentration } \\
>1.3 \mathrm{~nm}\end{array}$ & $1 \mathrm{~s}$ & $1.05 \mathrm{~nm}$ & PSM & $\mathrm{UH}$ & $\begin{array}{l}\text { White container } \\
\text { UH/Aerosol cottage }\end{array}$ \\
\hline $\begin{array}{l}\text { Aerosol particle number } \\
\text { concentration }\end{array}$ & $10 \mathrm{~min}$ & $\begin{array}{l}0.03-10 \mu \mathrm{m} \text { particle } \\
\text { sizes, } 12 \text { channels }\end{array}$ & Dekati ELPI & $\mathrm{UH}$ & Aerosol cottage \\
\hline Pollen & $1 \mathrm{~h}$ & 1 pollen grain & Spore trap & Univ. Huelva & HUMPPA tower \\
\hline Organic acids & $1 \mathrm{~min}$ & N/A & (-)-APCI-MS & Univ. Mainz & $\begin{array}{l}\text { Main SMEAR cottage, new } \\
\text { side }\end{array}$ \\
\hline Gly/Mgly & $8-24 \mathrm{~h}$ & $0.05-0.16 \mathrm{ng} \mathrm{m}^{-3}$ & Filter-LC-MS & Univ. Mainz & $\begin{array}{l}\text { Radiation tower near REA } \\
\text { cottage }\end{array}$ \\
\hline \multicolumn{6}{|l|}{ Chemical composition } \\
\hline $\begin{array}{l}\text { Particle chemical } \\
\text { composition }\end{array}$ & $5 \mathrm{~min}$ & $\sim 0.01 \mu \mathrm{g} \mathrm{m}^{-3 *}$ & AMS & $\mathrm{UH}$ & $\begin{array}{l}\text { Main SMEAR cottage, new } \\
\text { side }\end{array}$ \\
\hline $\begin{array}{l}\text { Particle chemical } \\
\text { composition }\end{array}$ & & $50 \mathrm{pg} *$ & Laser AMS & $\mathrm{UH}$ & $\begin{array}{l}\text { Main SMEAR cottage, new } \\
\text { side }\end{array}$ \\
\hline
\end{tabular}

\subsection{In situ comparison of $\mathrm{OH}$ measurement techniques}

Two main methods of determining ambient $\mathrm{OH}$ concentrations on-line are in use today. One is based on Laser Induced Fluorescence (LIF) (e.g. Martinez et al., 2010), and the second uses Chemical Ionization Mass Spectrometry (CIMS) (e.g. Petäjä, et al., 2009). The former technique has the advantage of simultaneously measuring $\mathrm{HO}_{2}$ which is itself an important photochemical species, whereas the latter also measures gaseous $\mathrm{H}_{2} \mathrm{SO}_{4}$, which is a key species in particle production. Although these two techniques have been previously compared for measuring $\mathrm{OH}$ in chamber studies (Schlosser et al., 2009; Fuchs et al., 2010), direct field comparisons are rare. Prior to the campaign, daytime $\mathrm{OH}$ measurements from the LIF and CIMS techniques were expected to be in good agreement, while interferences to the LIF measurement were expected to cause deviation only at night (Ren et al., 2003; Schlosser et al., 2009). When anomalies 
Table 1. Continued.

\begin{tabular}{|c|c|c|c|c|c|}
\hline $\begin{array}{l}\text { Aerosol phase } \\
\text { measurement }\end{array}$ & Time resolution & Detection Limit* & Technique & Institution & Inlet Location (Fig. 1) \\
\hline Organic acids & $8-24 \mathrm{~h}$ & N/A & Filter-LC-MS & UMainz & $\begin{array}{l}\text { Radiation tower near REA } \\
\text { cottage }\end{array}$ \\
\hline $\begin{array}{l}\text { Submicron organic mass } \\
\text { and functional group com- } \\
\text { position }\end{array}$ & $8 \mathrm{~h}$ & $0.1 .0 .4 \mu \mathrm{gm}^{-3}$ & Filter-FTIR & UCSD & White container UH (4 m) \\
\hline $\begin{array}{l}\mathrm{K}, \mathrm{Br}, \mathrm{S}, \\
\mathrm{Al}, \mathrm{V}, \mathrm{Cr}, \mathrm{Fe}, \mathrm{Cu}, \mathrm{Zn}, \mathrm{Se}\end{array}$ & $8 \mathrm{~h}$ & $1-100 \mathrm{ngm}^{-3}$ & Filter XRF & UCSD & White container UH (4 m) \\
\hline black carbon & $10 \mathrm{~min}$ & $5 \mathrm{ng} \mathrm{m}^{-3}$ & $\begin{array}{l}\text { Magee Scientific } \\
\text { Aethalometer }\end{array}$ & $\mathrm{UH}$ & Aerosol cottage \\
\hline $\begin{array}{l}\text { Ion and total size distribu- } \\
\text { tion } 0.8-40 \mathrm{~nm}\end{array}$ & $2 \min$ & $\sim 100 / \mathrm{cm}^{-3} *$ & ANAIS & UH & White container UH \\
\hline $\begin{array}{l}\text { Elemental and organic } \\
\text { carbon }\end{array}$ & $4 \mathrm{~h}\left(2 \mathrm{~m}^{3}\right)$ & $\begin{array}{l}\text { EC } 0.001 \mu \mathrm{gm}^{-3} \\
\text { OC } 0.8 \mu \mathrm{gm}^{-3}\end{array}$ & $\begin{array}{l}\text { Sunset EC/OC ana- } \\
\text { lyzer }\end{array}$ & UH & white container \\
\hline $\begin{array}{l}\mathrm{Cl}, \mathrm{NO}_{3}, \mathrm{SO}_{4}, \mathrm{Na}, \mathrm{NH}_{4}, \mathrm{~K} \\
\mathrm{Ca}, \mathrm{Mg} \text { in } \mathrm{PM}_{2.5} \text { and } \mathrm{PM}_{10}\end{array}$ & $60 \mathrm{~min}$ & $0.005-0.01 \mu \mathrm{g} \mathrm{m}^{-3}$ & MARGA & FMI & $\begin{array}{l}\text { Cabin }(2.5 \mathrm{~m}) \text {, close to } \\
\text { sawmill }\end{array}$ \\
\hline Biogenic organic acids & 2-3 days & & Filter-LC-MS & FMI & $\begin{array}{l}\text { container close to } \\
\text { sawmill }\end{array}$ \\
\hline \multicolumn{6}{|l|}{ Aerosol properties } \\
\hline $\begin{array}{l}\text { Cloud condensation nuclei } \\
\text { concentration } \\
\text { total + size segregated }\end{array}$ & $1 \mathrm{~s} / 10 \mathrm{~min}$ & & $\begin{array}{l}\text { Droplet Measure- } \\
\text { ment Technologies } \\
\text { CCN-100 }\end{array}$ & UH & Aerosol cottage \\
\hline Particle volatility & $15 \mathrm{~min}$ & $>20 \mathrm{~nm}$ & VDMPS & UH & Aerosol cottage \\
\hline $\begin{array}{l}\text { Particle volatility and hy- } \\
\text { groscopicity }\end{array}$ & $20 \mathrm{~min}$ & N/A & VHTDMA & UH & Aerosol cottage \\
\hline $\begin{array}{l}\text { Total particle concentration } \\
>3 \mathrm{~nm} \text {, solubility to water } \\
\text { and butanol }\end{array}$ & $10 \mathrm{~s}$ & $3 \mathrm{~nm}$ & $\mathrm{CPCB}$ & UH & Aerosol cottage \\
\hline \multicolumn{6}{|l|}{ Optical properties } \\
\hline Absorption coefficient & $1 \mathrm{~s}$ & & VPSAP & UH & Aerosol cottage \\
\hline Scattering coefficients & $2 \mathrm{~Hz}$ & & Vneph & $\mathrm{UH}$ & Aerosol cottage \\
\hline $\begin{array}{l}\text { Aerosol scattering Particle } \\
\text { volatility }\end{array}$ & $15 \min 10 \mathrm{~min}$ & N/A & $\begin{array}{l}\text { TSI } 3563 \text { Neph- } \\
\text { elometerVDMPS }\end{array}$ & UH & Aerosol cottage \\
\hline \multicolumn{6}{|l|}{ Atmospheric ions } \\
\hline Ion mass spectrum & $5 \mathrm{~s}$ & $1 / \mathrm{cm} 3$ per $5 \mathrm{~min}$ & API-ToF 1 & UH & White container UH \\
\hline Ion mass spectrum & $5 \mathrm{~s}$ & $1 / \mathrm{cm} 3$ per $5 \mathrm{~min}$ & API-ToF 2 & UH & \\
\hline Total ion concentration & $15 \mathrm{~s}$ & $\sim 100 / \mathrm{cm}^{-3} *$ & Gerdien & $\mathrm{UH}$ & White container UH \\
\hline Radon progeny & $1 \mathrm{~h}$ & & $\begin{array}{l}\text { filter } \\
\text { sampling \& beta } \\
\text { counting }\end{array}$ & FMI & aerosol cottage \\
\hline ambient radiation & $10 \mathrm{~min}$ & & Ionization chamber & FMI & aerosol cottage \\
\hline
\end{tabular}

PTR-MS = Proton Transfer Mass Spectrometer; CIMS = Chemical Ion Mass Spectrometer; CRD =Cavity Ring Down; GC-M=Gas Chromatography- Mass Spectrometry; GC-FID = Gas Chromatography- Flame Ionization Detector GC-PID = Gas Chromatography- Photo Ionization Detector; API-ToF = Atmospheric Pressure Ionization Mass Spectrometer; AMS = Aerosol Mass Spectrometer; CLD=Chemiluminensence detector; FTIR = Fourier Transform Infrared Spectroscopy; IRGA = Infrared absorption; UV = Ultraviolet absorption/fluorescence; CPCB Condensation Particle Counter Battery; PH-CPC Pulse-Height Analysis Condensation Particle Counter; PSM Particle Size Magnifier; VHTDMA Volatility-Hygroscopicity Tandem Differential Mobility Analyzer; VPSAP Volatility-Particle/Soot Absorption Photometer 3 B

Balanced Scanning Mobility Analyzer; ANAIS Airborne Neutral Cluster and Air Ion Spectrometer; Gerdien = Gerdien counter

作

$\mathrm{a}_{\text {for }} \mathrm{CH}_{3} \mathrm{C}(\mathrm{O}) \mathrm{NO}_{2}^{\mathrm{b}}$ varied in the course of the campaign 
between the $\mathrm{OH}$ measurements occurred, it was planned to exploit the comprehensive VOC and particle measurements to deduce possible causes. Thus a third campaign objective was set to perform a side-by-side comparison of $\mathrm{OH}$ in the VOC rich Boreal forest air and determine the identity of potential interferrents. These instruments measured together at ground level (Univ. Helsinki white container, see Fig. 1) to allow for comparison and subsequently the LIF instrument was moved to the top of the HUMPPA tower. In this way vertical gradients in $\mathrm{OH}$ could be assessed. The $\mathrm{OH}$ intercomparison revealed significant differences between the LIF and CIMS $\mathrm{OH}$ measurement, the former being up to a factor of ten higher (Novelli et al., 2011).

\subsection{Connections between VOC chemistry and Secondary Organic Aerosol formation, growth and ageing}

New particle events have been shown to be a regular occurrence at Boreal forest sites (Kulmala et al., 2001; Tunved et al., 2003). The mechanism of new particle formation and initial growth is currently not fully understood but thought to involve both $\mathrm{H}_{2} \mathrm{SO}_{4}$ and possibly also low volatility VOC oxidation products in the early stages (Kulmala et al., 2004). However, also the relative contribution of BVOC oxidation products to the growth of existing particles (i.e. regardless if they are involved in nucleation or early cluster growth) is an area of considerable uncertainty. Understanding the formation and growth of new particles requires knowledge of atmospheric chemistry, aerosol dynamics and meteorology all of which were measured with novel instrumentation during the HUMPPA-COPEC 2010 campaign. Atmospheric oxidation of the VOCs emitted by the Boreal forest leads to a suite of less volatile organic products. These may condense on existing particles or under certain circumstances form new particles. The co-located, simultaneous measurement of VOC composition, $\mathrm{OH}$-reactivity and physical (number, size and growth rates) and chemical (state and evolution of chemical composition) properties of aerosol particles allows potential links between BVOC oxidation and aerosol to be elucidated. Furthermore, the relationships between specific gas phase species and aerosol phase ions concentrations can be examined for causal links.

FTIR spectroscopy was used to quantify nearly $100 \%$ of the organic mass as aliphatic groups, carboxylic acid groups, organic hydroxyl groups, primary amine groups, and nonacid carbonyl groups (Russell et al., 2009). Organic functional groups in combination with elemental concentrations (measured by XRF) and other chemical measurements have been used to associate the functional group composition of the aerosol with biogenic and biomass-burning sources in other Boreal forests (Schwartz et al., 2010; Bahadur et al., 2010; Takahama, et al., 2011; Russell et al., 2011). However, the HUMPPA-COPEC campaign additionally provided the opportunity to associate these functional groups on submicron aerosol with specific biogenic precursors.

A comparison of vibrational sum frequency generation spectra of organic particles collected during HUMPPACOPEC to those from the Tropics has shown marked differences (Ebben et al., 2011). In the Boreal forest the secondary organic aerosol is similar in composition to aerosol generated from $\alpha$-pinene.

\subsection{Identification of the crucial molecules in atmospheric nucleation}

Our knowledge on the formation process for very small particles or clusters (sizes 1-2 nm) is still rather limited (see Kulmala et al., 2007; Kulmala and Kerminen, 2008). The question of which trace gases are involved in the atmospheric nucleation processes remains controversial within the aerosol community. It is likely that different nucleation mechanisms are at work under different conditions. The main candidates for nucleation in the troposphere have been thought to be: binary sulphuric acid - water (Noppel et al., 2002; Vehkamäki et al., 2002), ternary sulphuric acid - water - ammonia mixtures (Coffman and Hegg, 1995; Napari et al., 2002), ion induced nucleation of sulphuric acid and water (Lovejoy et al., 2004), activation of small clusters containing one sulphuric acid molecule (Kulmala et al., 2006), kinetic type, where critical clusters are formed by collisions of sulphuric acid molecules or other molecules containing sulphuric acid (McMurry and Friedlander, 1979) or nucleation by activation of organic molecules (Bonn et al., 2008). The comprehensive aerosol and gas-phase measurements provide the possibility to compare theoretical with measured nucleation rates (e.g. Boy et al., 2011) and to develop new parameterizations.

\subsection{Chiral signatures}

A sixth objective of this study was to fully investigate the chiral signature (enantiomeric ratios, distribution and temporal dependence) of the Boreal forest emissions. Typically these non-superimposable, mirror image forms of chemical species (stereoisomers such as (+)- $\alpha$-pinene and (-)$\alpha$-pinene) are measured and modeled together in ambient gas phase studies as they react with the same rates with ozone and $\mathrm{OH}$. However, the two enantiomers are biochemically distinct molecules which may elicit diverse responses in pollinators and predators within the biosphere. Previous studies have established that clear regional chiral signatures exist, and that ambient mixing ratios of $\alpha$-pinene enantiomers over the Boreal forest always favours (+)- $\alpha$-pinene (Williams et al., 2007). Furthermore, mechanical damage to the needles of the Scots pine has been shown to induce higher ratios of the (+) enantiomer (Yassaa and Williams, 2005, 2007), a finding that has proved useful in identifying emissions from a nearby sawmill (Eerdekens et al., 2009). Recently laboratory studies have shown that ozone reacting 
with stereoisomers on the surface of aerosol particles coated with chiral semivolatile organic compounds may depend on stereochemistry and that the differences in chemical accessibility could lead to the enrichment of one oxidation product stereoisomer over the other in ambient air (Stokes et al., 2009). To investigate whether such reactions impacted ambient enantiomeric distributions during HUMPPA-COPEC the enantiomeric monoterpenes were examined directly from the chamber (the emission signature, see Yassaa et al., 2011), from the ambient gas phase measurements (subject to photochemistry), and on the particle phase (by vibrational sum frequency and second harmonic generation analysis, see Ebben et al., 2011).

\subsection{Photochemistry and aerosol dynamics in biomass burning and city plumes}

While located in a remote, background area, the SMEAR II station can also be used for analyzing anthropogenic impacts on air composition. European Boreal forest regions in summer are prone to anthropogenic influences, both from biomass burning which commonly occurs in Boreal regions at this time of year, and from pollution plumes emerging from large urban centers (e.g. Helsinki, St. Petersburg). Both sources produce $\mathrm{NO}_{\mathrm{x}}\left(\mathrm{NO}\right.$ and $\left.\mathrm{NO}_{2}\right)$ and VOC, and thus can produce ozone photochemically during transport. Therefore the HUMPPA-COPEC campaign aimed to identify and characterize such plumes using back trajectories, as well as aerosol particle and trace gas signatures. In particular species such as formaldehyde, peroxy acyl nitrates (PANs), and peroxides were targeted in this regard. Furthermore, it was hoped to assess the response of the forest to elevated anthropogenic ozone levels in such periods, in particular through analysis of ozone dry deposition flux measurements in relation to photosynthesis and micrometeorological measurements.

\subsection{Dependence of diel $\mathrm{OH}$ and its precursors on meteorology}

The HUMPPA-COPEC 2010 campaign offers a unique opportunity to investigate the impact of physical and meteorological parameters on $\mathrm{OH}$ and its related precursors within the boreal forest environment. By analyzing the surface characteristics (fluxes of heat, moisture, momentum and reactive species), the boundary layer dynamics, the evolution of the thermodynamic variables, UV-radiation field and the chemical pathways, the processes controlling the diurnal variability of $\mathrm{OH}$ can be determined. Previous studies in tropical regions (Ganzeveld et al., 2008 and Vilà-Guerau de Arellano et al., 2011) have shown the importance of the night-day transition, the onset of biogenic emissions and the exchange of the residual layer (free troposphere) with the boundary layer in controlling the maximum concentrations of $\mathrm{NO}$, isoprene and $\mathrm{OH}$.
In order to achieve the objectives set in Sect. 2.2 and 2.7, modeling tools were applied (box-, 1-D and large-eddy simulation models) and the capabilities of these tools in reproducing the main features of the diurnal variability of $\mathrm{OH}$ and biogenic compounds were assessed. The subsequent sensitivity analyses then allowed for a determination of the different roles of the boundary layer dynamics, emissions/deposition and chemistry in the OH-reactivity. The evolution and the structure of the atmospheric boundary layer and the turbulent mixing inside are important parameters controlling the chemical reactions and aerosol dynamics usually observed at ground level. The main height at which new particles form remains controversial and recent findings in atmospheric modeling suggest that reactive organic compounds emitted from the canopy or soil with a strong gradient in the entrainment zone at the top of the atmospheric mixed layer are needed to explain the observed vertical distribution (Boy et al., 2011). Both nucleation events and failed events during HUMPPA-COPEC will be examined to this end.

\subsection{Atmospheric nitrogen budget for the Boreal forest}

A comprehensive suite of nitrogen containing compounds in the air was measured during the HUMPPA-COPEC campaign. In the gas phase $\mathrm{NO}, \mathrm{NO}_{2}, \mathrm{~N}_{2} \mathrm{O}_{5}, \mathrm{NO}_{3}, \mathrm{HNO}_{3}$, PANs, $\mathrm{NH}_{3}$ and $\mathrm{HONO}$ were quantified, while in the aerosol phase nitrate $\left(\mathrm{NO}_{3}^{-}\right)$and ammonium $\left(\mathrm{NH}_{4}^{+}\right)$were also monitored on-line. The instruments used for each species are detailed in Table 1. How nitrogen species are processed over the Boreal forest is examined in detail in this special issue, in particular with regard to interactions with oxidants such as $\mathrm{OH}$ and $\mathrm{O}_{3}$.

\section{Instrumentation}

The Hyytiälä station (SMEAR II) is one of three stations operated throughout the year by the University of Helsinki (Hari and Kulmala, 2005). Several key instruments are run with a high degree of automation at the SMEAR II-Hyytiälä site throughout the year (e.g. $\mathrm{O}_{3}, \mathrm{CO}_{2}, \mathrm{CO}$, meteorological parameters) and the data made available to the public via the SMEARsite (http://www.atm.helsinki.fi/ junninen/ smartSearch), details of which are provided by Junninen et al., 2009. During the HUMPPA-COPEC 2010 campaign, the standard suite of measurements was extended between July and August. A full list of instruments operated during the HUMPPA-COPEC campaign is given in Table 1.

The location of each instrument and its inlet can be seen in Table 1 and Fig. 1. Many of the instruments associated with the intensive period positioned inlets on the HUMPPA tower $(24 \mathrm{~m})$, extending approximately $2-3 \mathrm{~m}$ above the canopy top. For photochemical studies it is essential that measurements of reactive species (e.g. $\mathrm{OH}, \mathrm{CH}_{2} \mathrm{O}$, and monoterpenes), and their photochemical source $\left(J \mathrm{NO}_{2}, J \mathrm{O}^{1} \mathrm{D}\right)$ and sink terms $\left(\mathrm{OH}\right.$ reactivity, $\left.\mathrm{O}_{3}, \mathrm{NO}_{3}\right)$ be collocated due to 


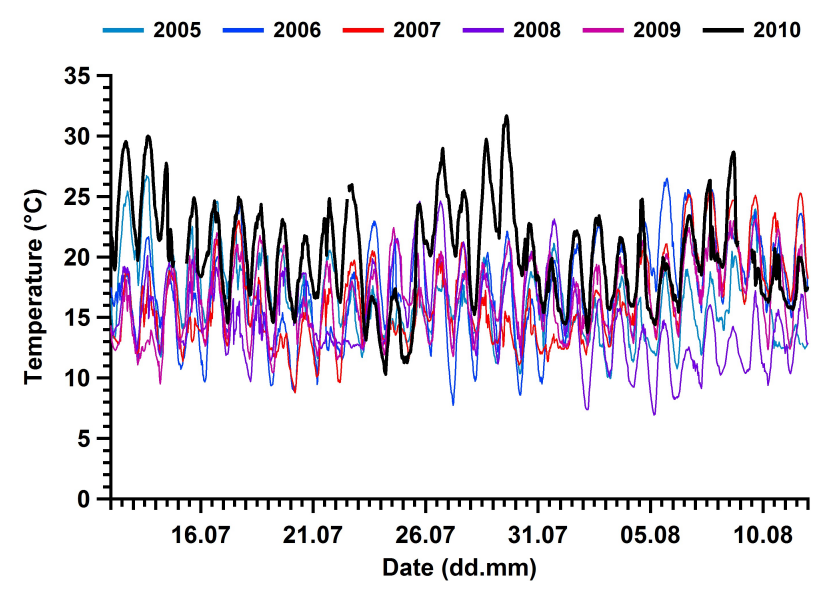

Fig. 2a. Temperature recorded in Hyytiälä between July and August from 2005-2010 from mast at $33.6 \mathrm{~m}$.

their inherently high spatial variability. Furthermore, close proximity of $\mathrm{OH}$ and reactive organic inlets is essential when investigating intensity of segregation effects that can effectively reduce the overall rate of isoprene oxidation due to inhomogeneous mixing (e.g. Butler, 2008; Pugh et al., 2011). These instruments were situated preferentially around the HUMPPA tower in a 3-container stack, and MPI white container. Due to space constraints most aerosol instruments were located at the main aerosol hut. Less reactive gas phase species (e.g. alkanes) and measurements with long integrating times (aerosol filters) were placed in alternative locations close by (main aerosol hut, MPI blue container) due to space constraints. All measurements were made within a radius of $300 \mathrm{~m}$ from the main mast, see Fig. 1. In the following analysis of regional influences on the site (see Sect. 5.0), all measurements are considered to be collocated.

The height of the forest canopy was generally $20-21 \mathrm{~m}$ though the land surrounding the site was slightly undulating so that the forest crown was not in one horizontal plane. From the $73 \mathrm{~m}$ mast (see Fig. 1), measurements of selected species (e.g. $\mathrm{O}_{3}, \mathrm{CO}_{2}$ ) as well as meteorological parameters were made at multiple heights $(4 \mathrm{~m}, 8 \mathrm{~m}, 16 \mathrm{~m}, 33 \mathrm{~m}, 50 \mathrm{~m}$ $67 \mathrm{~m}$ ). Further vertical resolution of temperature and pressure was obtained through the regular launching of meteorological sondes to approximately $5 \mathrm{~km}$ (ca. 4 times per day). Several other instruments measured both above and below the canopy (e.g. OH reactivity and monoterpenes.)

In addition to the in situ measurements of gas phase and aerosol species, several branch cuvette systems were employed to measure the emission fluxes of monoterpenes and sesquiterpenes from several chemotypes of pine and spruce near the VOC tower and additionally $\mathrm{CO}_{2}$ uptake rates at the photo tower. Furthermore, from the main mast direct flux (disjunct eddy covariance and gradient method) measurements of several VOC species in air were performed us-

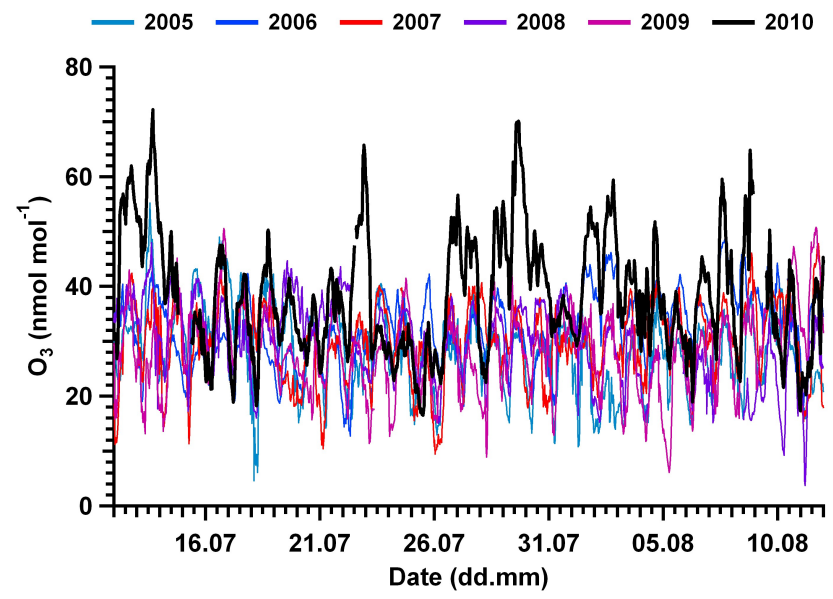

Fig. 2b. Ozone (30 min average) recorded in Hyytiälä between July and August from 2005-2009 from mast at $16.8 \mathrm{~m}$ and 2010 from $33.6 \mathrm{~m}$.

ing PTR-MS, while fluxes of species from the ground were also monitored via automated flux chamber analyses.

\section{Meteorology}

\subsection{General}

For the campaign period (July-August 2010) the Hyytiälä site was influenced by a high pressure region centered to the east of Finland and a sequence of weak frontal systems. Surface pressures varied between $980-1005 \mathrm{hPa}$, and due to the northern latitude there was approximately $18 \mathrm{~h}$ daylight per day. The temperatures measured at the site (at $16.8 \mathrm{~m}$ ) in this period were anomalously high $\left(T_{\max }=32.4, T_{\min }=10.1\right.$, $\left.T_{\text {ave }}=20.0^{\circ} \mathrm{C}\right)$. Indeed the highest temperature recorded anywhere in Finland for 100 years $\left(37.2^{\circ} \mathrm{C}\right)$ was registered during this campaign, albeit not at the Hyytiälä site. The measurements during these high temperature conditions may hold clues about the forest response to future climate change. Figure 2a shows the temperatures recorded at the Hyytiälä site for the campaign period over the past 6 years. The temperatures in 2005, 2006, 2007, 2008, and 2009 show a similar spread of temperatures $\left(6-25^{\circ} \mathrm{C}\right)$ while in 2010 temperatures exceeded $25^{\circ} \mathrm{C}$ for several periods (e.g. 10-14 July, 27-30 July). The temperatures were not, however, anomalously high for the whole campaign. Cooler periods (e.g. 23$25 \mathrm{July}$, average temperature $14^{\circ} \mathrm{C}$ ) were recorded, in particular associated with air from the northwest. Interestingly, the levels of ozone for 2010 were also anomalously high (see Fig. 2b), the highest levels corresponding closely to the highest temperatures. Again, this may not be untypical for future conditions. Precipitation was generally low $\left(<2 \mathrm{~mm} \mathrm{day}^{-1}\right)$ except for 15 July, 27 July and 4 August when heavier rain 
Table 2. Time periods are tabulated according to wind sector alongside key events noted within these time periods.

\begin{tabular}{|c|c|c|}
\hline \multicolumn{2}{|c|}{ Southwest (SW) } & Comment \\
\hline Start & End & \\
\hline 10/7/10 03:00 & 13/7/10 09:00 & Pollution event with high small particles and high accumulation mode (12 July). \\
\hline 15/7/10 09:00 & 16/7/10 00:00 & Rain. Pollution from Poland/Germany, peaks in pentane and CO. \\
\hline 18/7/10 15:00 & 22/7/10 15:00 & \\
\hline 27/7/10 21:00 & 28/7/10 18:00 & \\
\hline 30/7/10 18:00 & $3 / 8 / 1021: 00$ & Sawmill at 18:00-23:00 (3/8) identified by alpha pinene stereoisomers. \\
\hline 5/8/10 00:00 & $7 / 8 / 1015: 00$ & Sawmill at 00:00 (6/8) identified by alpha pinene stereoisomers. \\
\hline 10/8/10 03:00 & 12/8/10 21:00 & \\
\hline \multicolumn{3}{|c|}{ Southeast (SE) } \\
\hline Start & End & \\
\hline 13/7/10 18:00 & 15/7/10 00:00 & Three defined peaks of high $\mathrm{SO}_{2}$. Pollution from St. Petersburg, Russia. \\
\hline $16 / 7 / 1015: 00$ & 17/7/10 03:00 & \\
\hline 27/7/10 00:00 & 27/7/10 18:00 & High temp, smoke from Russian fires, high $\mathrm{CH} 3 \mathrm{CN}, \mathrm{CO}, \mathrm{SO}_{2}$. \\
\hline 28/7/10 21:00 & 30/7/10 15:00 & High temp, smoke from Russian fires, high $\mathrm{CH} 3 \mathrm{CN}, \mathrm{CO}, \mathrm{SO}_{2}$. \\
\hline 4/8/10 18:00 & $5 / 8 / 1012: 00$ & \\
\hline 8/8/10 00:00 & 10/8/10 00:00 & Smoke from Russian fires, high $\mathrm{CH} 3 \mathrm{CN}, \mathrm{CO}, \mathrm{SO}_{2}$. \\
\hline \multicolumn{3}{|c|}{ Northwest (NW) } \\
\hline Start & End & \\
\hline 17/7/10 00:00 & $18 / 7 / 1012: 00$ & High ambient temp, high alpha pinene. Sawmill event 04:00 (18/7). \\
\hline 23/7/10 12:00 & 25/7/10 12:00 & Very clean, cool ambient temp. Nucleation event 23 July, 06:00-14:00. \\
\hline
\end{tabular}

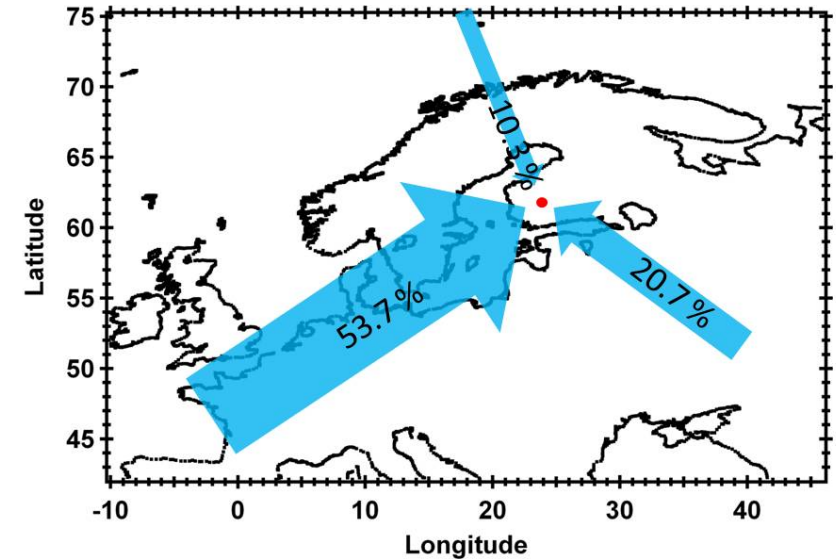

Fig. 3a. A map showing schematically the proportion of airmasses influencing the site during the HUMPPA-COPEC campaign, deduced from 3 day back trajectory analysis and segregated into wind sectors (NW, NE, SW, SE). The arrow sizes approximate to the proportion of trajectories and the statistics of the analysis are given in Table 3.

events (associated with frontal passages) were experienced at the site. On several occasions these rain events and associated lightning caused power disruption at the site.

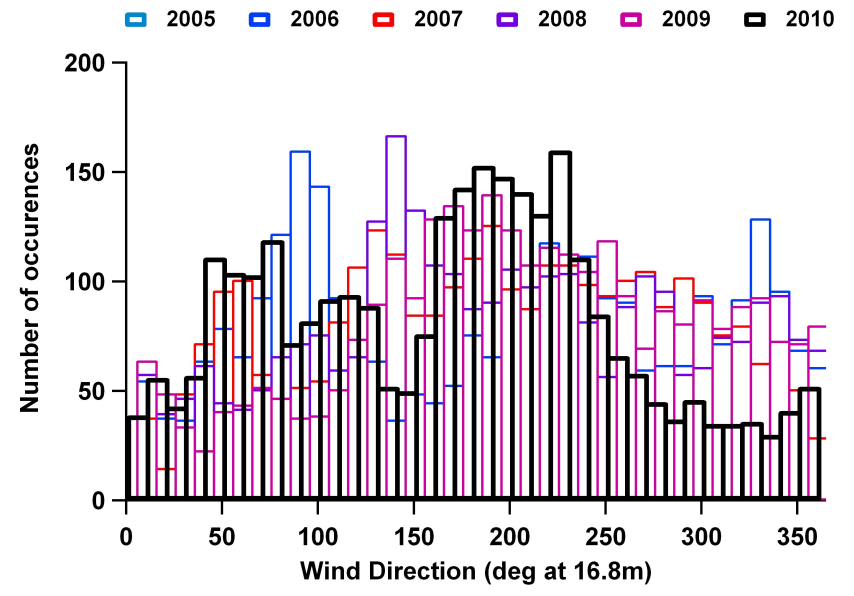

Fig. 3b. A histogram of wind direction for the HUMMPA-COPEC 2010 campaign period ( $5 \mathrm{~min}$ average), compared to those taken from the years 2005-2009. Data from $16.8 \mathrm{~m}$ on the main mast.

\subsection{Air mass origin}

Three day air mass back trajectories were compiled for the duration of the HUMPPA-COPEC campaign. The trajectories were calculated every $3 \mathrm{~h}$ starting from 00:00 UTC, from a height of $25 \mathrm{~m}$ (a.g.1.), between 10 July and 12 August using the National Oceanic and Atmospheric Administration (NOAA) GDAS database, which applies the Hybrid Single- 

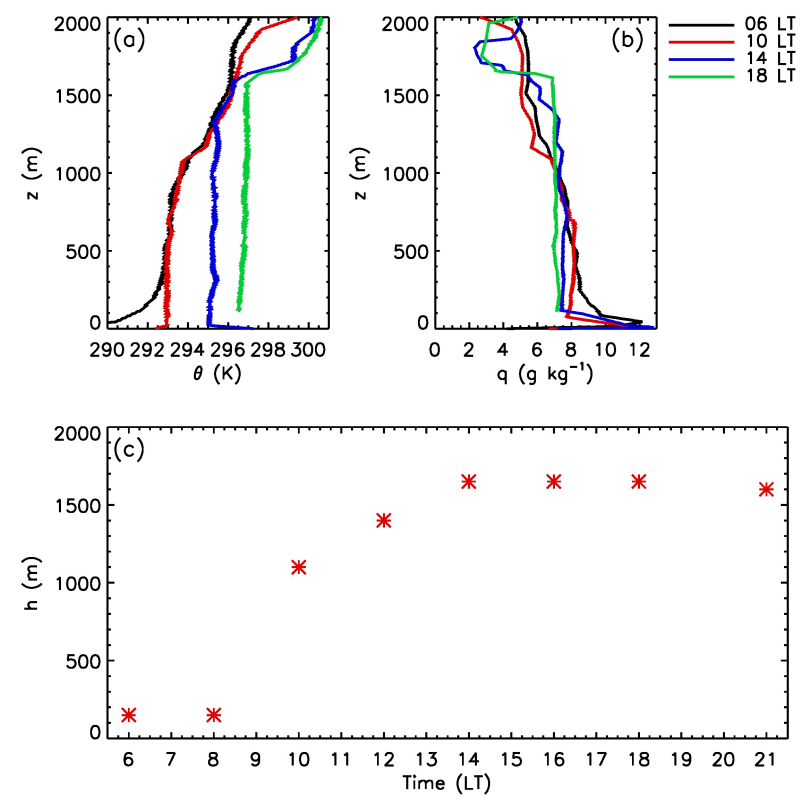

Fig. 4. (a) and (b) Evolution of the vertical profiles of potential temperature and specific humidity measured the 6 August 2010 (06:00, 10:00, 14:00 and 18:00 LT). (c) Estimation of the boundary layer height evolution calculated from the vertical profile radiosondes.

Particle Lagrangian Integrated Trajectories (HY-SPLIT 4) program (Draxler and Rolph, 2011; Rolph, 2010). The three day trajectory endpoints were found to partition into three distinct sectors relative to the Hyytiälä site (NW, SW and $\mathrm{SE})$. This trajectory derived air mass origin information is summarized in Fig. 3a. For most of the 2010 campaign air advected to the site originated three days previously from the SW (53.7\%), although significant periods of SE (20.7\%) and NW (10.3\%) air were also encountered. These trajectories correspond closely to the distribution of wind directions measured at $16.8 \mathrm{~m}$ shown in Fig. $3 \mathrm{~b}$. Figure $3 \mathrm{~b}$ also includes wind direction data from the previous 5 years for comparison and it shows that 2010 had more southerly and less northwesterly influence than in previous years. Table 2 summarizes the time periods each sector influenced the site. Conditions generally remained steady for $2-3$ days at a time, which is typical of synoptic scale frontal system influences mentioned in Sect. 4.1. Also included in Table 2a are the local and regional influences (e.g. biomass burning) observed during each time period. These are discussed in more detail below in Sect. 5 .

In order to determine whether the anomalously high temperatures experienced during this campaign were related to anomalous circulation patterns, a similar trajectory analysis to that presented above for 2010 was also performed for the years 2005-2009 and the results presented in Table 3. For the years 2010, 2009 and 2007 southwesterly flow was dominant in summer. However, in 2006 and 2008 the prevail- ing wind direction was northwesterly which has been identified as the wind sector least impacted by anthropogenic pollution and thus most representative of pristine Boreal forest (Tunved et al., 2006). The year 2010 has a significantly larger proportion of trajectories from the south than all other years analyzed (74.4\%) and this is likely the reason for the higher temperatures and ozone experienced in 2010. High $\mathrm{O}_{3}$ levels $\left(>120 \mu \mathrm{g} \mathrm{m}^{-3}\right)$ in several other Southern Finland stations of the National Air Quality measurement network (FMI, http://www.ilmanlaatu.fi/ilmanyt/ylitykset/ rajaarvoylitys.php?p=O $\$\{3\} \$ M 8\{\backslash \&\} y s=2010)$, were also reported during July-August 2010, indicating long-range transport from Central Europe.

\subsection{Atmospheric boundary layer characteristics}

The measurements of turbulent fluxes of heat, moisture and momentum at the surface (SMEAR II tower) combined with the profiling of the thermodynamic variables enable us to characterize the atmospheric boundary layer (ABL) dynamics during the campaign. The vertical structure of the ABL during night and day was monitored by 175 radiosondes launched throughout the campaign. In order to obtain a detailed quantification of the evolution of the ABL, we scheduled 5 intensive observation days $(24 \mathrm{~h})$ with radiosonde launches every $2 \mathrm{~h}$. From these observations (temperature, pressure, humidity), the evolution of the boundary layer height and the dynamic characteristics of the entrainment zone can be determined. In Fig. $4 a$ and $b$ an example is shown of the evolution of the vertical profiles of potential temperature $(\mathrm{O})$ and specific humidity $(q)$ at 06:00, 10:00, 14:00 and 18:00 local time (LT) of 6 August 2010 (SW sector, see Table 2). At 06:00 LT a ground inversion (extending up to approximately $150 \mathrm{~m}$ ) with a residual layer is clearly observed. The profile at 10:00 LT already shows a well mixed boundary layer extending up to $1100 \mathrm{~m}$ and capped with a thermal inversion $(\sim 2 \mathrm{~K})$ at the same height. We note the well mixed profile of specific humidity at 14:00 and 18:00 LT, indicating the effectiveness of convective turbulence in mixing the species. For example, at 14:00 LT the free convection time scale (Stull, 1988) is estimated to be around $10 \mathrm{~min}$.

Figure $4 \mathrm{c}$ shows the boundary layer height $(h)$ estimated from the vertical profiles of potential temperature. Several criteria can be used to estimate $h$, but in this case the maximum potential temperature gradient near the inversion layer has been used. Note the strong temperature gradient at $2 \mathrm{~km}$ is not connected to the current boundary layer, but to advection and residual layers and is therefore not considered. As the figure shows, the boundary layer height typically grows from less than $200 \mathrm{~m}$ in the early morning to around $1700 \mathrm{~m}$ at the end of the afternoon. After the ground inversion has broken up (after 08:30 LT), the boundary layer connects with the residual layer aloft and is rapidly merged. After this, the boundary layer resumes its growth by entrainment. In spite 
Table 3. The percentage distribution within the sectors (NW, SW, SE, NE) are shown for the years 2005-2010.

\begin{tabular}{llllll}
\hline & \multicolumn{5}{c}{ Percentage trajectory distribution by sector } \\
\cline { 2 - 6 } Year & South-West & South-East & North-West & North-East & Trajectories Used \% \\
\hline 2010 & 53.7 & 20.7 & 10.3 & 0 & 84.7 \\
2009 & 53.7 & 3.7 & 0.5 & 16.2 & 74.1 \\
2008 & 29.4 & 0 & 34.6 & 14 & 78 \\
2007 & 44.1 & 18.4 & 16.9 & 2.2 & 81.6 \\
2006 & 21.3 & 27.9 & 34.6 & 14.7 & 98.5 \\
2005 & 29.4 & 18.4 & 23.5 & 0.7 & 72 \\
\hline
\end{tabular}
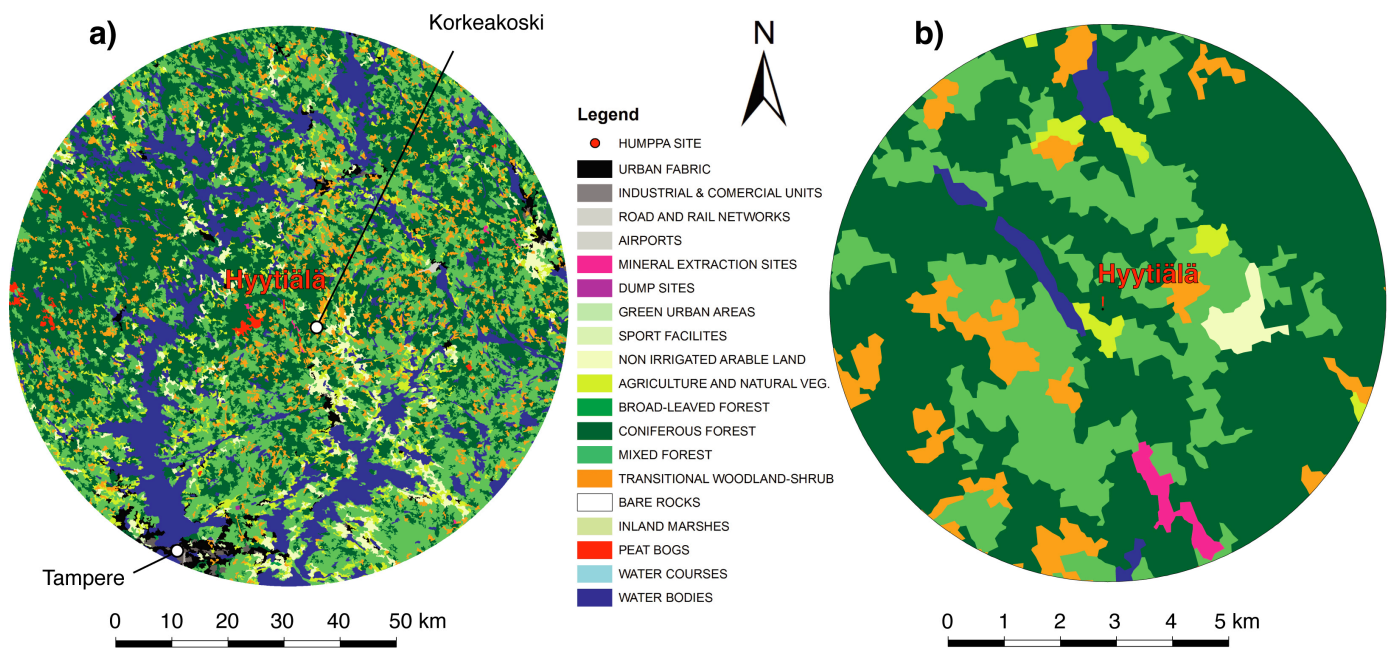

Fig. 5. Land use plots extracted from the Corine (2006) database for a $50 \mathrm{~km}$ and $5 \mathrm{~km}$ radius around the Hyytiälä site.

of the large sensible heat flux at the surface (maximum value of $350 \mathrm{~W} \mathrm{~m}^{-2}$ near noon), the final boundary layer height was less than expected, possibly due to subsidence and differences in horizontal heat advection between the boundary layer and free troposphere, which can be induced by horizontal differences in land use conditions. Model results show that not taking this into account leads to an overestimation of $600 \mathrm{~m}$ of the boundary layer height at $18 \mathrm{LT}$. Governing dynamic factors (surface fluxes, role of entrainment and advection, clouds) need to be considered in the data analysis since they influence the transport and mixing of the reactant species. A complete analysis of the boundary layer dynamics and its implications to the $\mathrm{OH}$ reactivity in the Boreal forest is provided elsewhere in this special issue.

\section{Local and regional influences}

\subsection{Land use within $50 \mathrm{~km}$ and $5 \mathrm{~km}$ of the Hyytiälä station}

Potential local and regional influences on measurements at the Hyytiälä station were assessed within a $50 \mathrm{~km}$ and $5 \mathrm{~km}$ radius of the site using the Corine land cover database
(EEA Technical Report, 1997). The data were edited using the ArcGis 9.2 (Esri ()) Geographic Information Systems (GIS) software. These radii were chosen based on the typical summer atmospheric lifetimes of one of the main biogenic species namely $\alpha$-pinene. Assuming an $\mathrm{OH}$ concentration of $1 \times 10^{6}$ and ozone $1 \times 10^{12}$ molecules $\mathrm{cm}^{-3}$ $\left(0.04 \mathrm{pmol} \mathrm{mol}^{-1}\right.$ and $\left.40 \mathrm{nmol} \mathrm{mol}^{-1}\right)$ the atmospheric lifetime of $\alpha$-pinene is approximately $2 \mathrm{~h}$ based on laboratory measured rate coefficients (Atkinson al., 2006). Wind speeds measured at $68 \mathrm{~m}$ during the campaign varied between 0.1 $7.0 \mathrm{~ms}^{-1}$ with an average of $2 \mathrm{~ms}^{-1}$. Thus the distances covered at these wind speeds within one $\alpha$-pinene lifetime approximate to $5 \mathrm{~km}$ and $50 \mathrm{~km}$, respectively.

Figure 5 shows the distribution of land use within 50 and $5 \mathrm{~km}$ of the Hyytiälä site. On both scales the majority of the surrounding area is forested and this is consistent with the analysis of Finnish map information presented by Haapanala et al., 2007. There is one significant urban centre visible on the 50km plot namely Tampere (population 211000 ), which was southwest of the site and therefore within the prevailing wind sector, see Sect. 4.2. Tables $4 \mathrm{a}$ and $\mathrm{b}$ give the area covered by specific land use types within $50 \mathrm{~km}$ and $5 \mathrm{~km}$ of Hyytiälä, respectively. The data is presented as a total and 
as a function of the wind sectors identified in Sect. 4. It can be seen from the $50 \mathrm{~km}$ scale analysis that coniferous forest and mixed forest account for over $65 \%$ of the land use surrounding Hyytiälä. Small or medium sized water bodies are also significant within the region comprising some $15 \%$ of the area within $50 \mathrm{~km}$, which is representative of Finland. Closer examination of the individual sector analyses for the $50 \mathrm{~km}$ radius shows that the Northwest sector has the highest percentage of coniferous forest. This is in agreement with Tunved et al., 2006 who identified this sector as representing the pristine boreal forest with minimum anthropogenic influence. It should be noted, however, that wind only came from the sector for circa $10 \%$ of the campaign. The south west sector (corresponding to the prevailing wind) shows the largest percentage of urban fabric $(4.3 \%)$, although this is still small in comparison to the combined total of coniferous and mixed forest (59\%). The influence of anthropogenic sources is discussed further in Sect. 5.4. The dominance of the forest cover also extends to the southeast sector although here a somewhat higher percentage of agriculture and arable land is evident. Within $5 \mathrm{~km}$ of Hyytiälä the coverage due to coniferous and mixed forest increases to approximately $80 \%$ in all sectors. Inclusion of the category "transitional woodland scrub", which was regenerated forested land in the seedling or sapling stage, increases this coverage to over $90 \%$ in all wind sectors and to $94 \%$ of the overall land use within $5 \mathrm{~km}$. An inspection of the areas designated by the Corine land cover database as coniferous forest, mixed forest and woodland scrub was performed within $5 \mathrm{~km}$ of the site. Those areas identified as coniferous forests were found to be Scots pine (Pinus sylvestris L.) and Norway spruce (Picea abies L. [Karst.]) which have been identified previously as strong terpene emitters. Example forests of these trees, located within $5 \mathrm{~km}$ of the Hyytiälä site, are shown in Fig. 6 . The most extensive "coniferous" species over Finland as a whole is Scots pine (Pinus sylvestris), although the Norway spruce (Picea abies) is also common. The areas classified as mixed forests, see Fig. 6, were found to include conifers and deciduous trees, mainly birches such as Silver birch (Betula pendula Roth) and lesser extent Downy birch (B. pubescens Ehrh). Woodland scrub included species such as willow (Salix sp.) and aspen (Populus sp.), which are both known to be emitters of isoprene (Hakola et al., 1998; Rinne et al., 2009).

\subsection{Biomass burning}

A consequence of the region-wide heatwave was that numerous devastating wildfires began mid July in the NidzniNovgorod region of the Russian Federation, some $400 \mathrm{~km}$ east of Moscow. The burning continued for one month, causing over 50 casualties and leaving thousands homeless. By August 18 an estimated 5.8 million ha had burned in the region (http://www.fire.uni-freiburg.de). The fires significantly impacted regions of dry peatlands but also extended to wheat and timber. The biomass burning emissions were advected over Moscow and beyond. In Fig. 7 it can be seen that clear biomass burning signals were detected at the SMEAR II Hyytiälä station on three distinct occasions. These were: event 1-26 July, 00:00 and 28 Juluy, 00:00; event 2-28 July, 12:00 and 30 July, 12:00; event 3-7 August, 12:00 and 9 August, 18:00, with all times in local time (UTC + 3). Acetonitrile $\left(\mathrm{CH}_{3} \mathrm{CN}\right)$, a specific marker for biomass burning (Lobert et al., 1990) and CO a general marker for combustion increased significantly during these periods. Additional ensemble type back trajectories for these periods indicated that the air arriving at the Hyytiälä site had passed over the burning affected Novgorod region. These incidences are also noted in Table 2.

\subsection{Sawmill influence}

In the course of a previous campaign in Hyytiälä (QUEST IV) the occasional influence of nearby sawmill activity at Korkeakoski $\left(330000 \mathrm{~m}^{3}\right.$ wood per year, $10 \mathrm{~km} \mathrm{SE} \mathrm{from}$ Hyytiälä) was noted (Eerdekens et al., 2009). In Korkeakoski the "UPM" sawmill was in operation from 2-13 August, the "JPJ" woodmill operated between 9-12 August and the Paahtopuu pellet factory operated between 12-13 August. This influence manifested itself as unusually high concentrations of monoterpenes and as a strong enrichment of $(+)-\alpha$-pinene over its ( -$)-\alpha$-pinene enantiomer. These events were also associated with a southeasterly wind direction corresponding to the bearing of the mill from the site, see Fig. 5. Figure 8 shows the sum concentration of both $\alpha$-pinene enantiomers and their ratio for the 2010 HUMPPA-COPEC campaign. On several occasions, peak concentrations are associated with enantiomeric ratio enrichments in (+)- $\alpha$-pinene. These events coincide with short episodes of southeasterly winds suggesting that sporadic influences of the sawmill were detected during the campaign. Case studies of these events, which increase for short periods to an order of magnitude higher than average values, can help elucidate the efficiency of $\mathrm{OH}$ radical recycling as a function of monoterpene concentrations. Two strong events were noted in the campaign: event 1, 18 July 2010, 01:00-06:45 LT, wind direction $114-122^{\circ},(-) /(+) \alpha$-pinene ratio $0.38-0.48$; and event 2, 6 August 2010, 01:40-04:00 LT, wind direction 109-200', $(-) /(+) \alpha$-pinene ratio $0.35-0.49$. These incidences are also noted in Table 2. Several other short transient events are noted: event 3, 4 August 2010, 09:45 LT; event 4, 3 August 2010, 20:10 LT; event 5, 3 August 2010, 23:25 LT.

\subsection{Urban/anthropogenic influence}

Clear anthropogenic influences on the Hyytiälä dataset can be deduced from the $\mathrm{SO}_{2}$ and n-pentane traces shown in Fig. 9. Both species are anthropogenically emitted. A strong peak of $\mathrm{SO}_{2}$, in excess of $2 \mathrm{nmol} \mathrm{mol}^{-1}$, can be seen on 14 July and this corresponds to ensemble back trajectory 
Table 4. Land use within (a) $50 \mathrm{~km}$ and (b) $5 \mathrm{~km}$ of the Hyytiälä site expressed in areas of activity/vegetation $\left(\mathrm{m}^{2}\right)$, extracted from the European Corine landcover database 2006, defined in GIS nomenclature for types with significant coverage.

\begin{tabular}{|c|c|c|c|c|c|c|c|c|c|c|c|}
\hline CLC code & Land use & $5 \mathrm{~km}$ radius & $\%$ & NW & $\%$ & $\mathrm{NE}$ & $\%$ & SW & $\%$ & SE & $\%$ \\
\hline \multicolumn{12}{|l|}{ (a) } \\
\hline 131 & MINERAL EXTRACTION SITES & 799736 & 1.02 & - & - & - & - & - & - & 799736 & 4.07 \\
\hline 211 & NON IRRIGATED ARABLE LAND & 979787 & 1.25 & - & - & 169447 & 0.86 & - & - & 810339 & 4.13 \\
\hline 243 & AGRICULTURE AND NATURAL VEG. & 1418096 & 1.81 & 376096 & 1.91 & 599626 & 3.05 & 232133 & 1.18 & 210241 & 1.07 \\
\hline 312 & CONIFEROUS FOREST & 47634279 & 60.65 & 11035479 & 56.18 & 13513179 & 68.77 & 9280674 & 47.31 & 13804947 & 70.34 \\
\hline 313 & MIXED FOREST & 20093416 & 25.58 & 5607809 & 28.55 & 4706291 & 23.95 & 6353074 & 32.38 & 3426243 & 17.46 \\
\hline 324 & TRANSITIONAL WOODLAND-SHRUB & 5988018 & 7.62 & 1358042 & 6.91 & 635479 & 3.23 & 3593061 & 18.31 & 401437 & 2.05 \\
\hline 412 & PEAT BOGS & 200 & 0.00 & - & - & - & - & - & - & 200 & 0.00 \\
\hline 512 & WATER BODIES & 1624184 & 2.07 & 1265198 & 6.44 & 26115 & 0.13 & 159784 & 0.81 & 173087 & 0.88 \\
\hline TOTAL & & 78537716 & 100.00 & 19642624 & 100.00 & 19650137 & 100.00 & 19618725 & 100.00 & 19626230 & 100.00 \\
\hline \multicolumn{12}{|l|}{ (b) } \\
\hline 112 & URBAN FABRIC & 150558427 & 1.92 & 8485697 & 0.43 & 36426790 & 1.86 & 86855484 & 4.42 & 18790456 & 0.96 \\
\hline 121 & INDUSTRIAL \& COMERCIAL UNITS & 23592576 & 0.30 & 319679 & 0.02 & 5348448 & 0.27 & 16436387 & 0.84 & 1488062 & 0.08 \\
\hline 122 & ROAD AND RAIL NETWORKS & 1126124 & 0.01 & - & - & - & - & 1126124 & 0.06 & - & - \\
\hline 124 & AIRPORTS & 3149041 & 0.04 & - & - & 2674572 & 0.14 & 474469 & 0.02 & - & - \\
\hline 131 & MINERAL EXTRACTION SITES & 6341889 & 0.08 & 711848 & 0.04 & 2835160 & 0.14 & 1348211 & 0.07 & 1446671 & 0.07 \\
\hline 132 & DUMP SITES & 579153 & 0.01 & - & - & - & - & 579153 & 0.03 & - & - \\
\hline 141 & GREEN URBAN AREAS & 2387588 & 0.03 & - & - & - & - & 2387588 & 0.12 & - & - \\
\hline 142 & SPORT FACILITES & 1834799 & 0.02 & 369541 & 0.02 & - & - & 1465258 & 0.07 & - & - \\
\hline 211 & NON IRRIGATED ARABLE LAND & 280857774 & 3.58 & 52112278 & 2.65 & 41410514 & 2.11 & 56404043 & 2.87 & 130930938 & 6.67 \\
\hline 243 & AGRICULTURE AND NATURAL VEG. & 455058805 & 5.79 & 88612866 & 4.51 & 94848407 & 4.83 & 128493825 & 6.54 & 143103707 & 7.29 \\
\hline 311 & BROAD-LEAVED FOREST & 5106062 & 0.07 & 1371976 & 0.07 & 2530390 & 0.13 & 1203696 & 0.06 & - & - \\
\hline 312 & CONIFEROUS FOREST & 2940247806 & 37.44 & 1050577913 & 53.51 & 762613505 & 38.84 & 624444341 & 31.80 & 502612048 & 25.60 \\
\hline 313 & MIXED FOREST & 2268757841 & 28.89 & 366556849 & 18.67 & 608511742 & 30.99 & 566350837 & 28.84 & 727338414 & 37.04 \\
\hline 324 & TRANSITIONAL WOODLAND-SHRUB & 466920775 & 5.95 & 97151907 & 4.95 & 172311046 & 8.78 & 90304904 & 4.60 & 107152917 & 5.46 \\
\hline 332 & BARE ROCKS & 253594 & 0.00 & 253594 & 0.01 & - & - & - & - & - & - \\
\hline 411 & INLAND MARSHES & 5551667 & 0.07 & 832045 & 0.04 & 303817 & 0.02 & 402731 & 0.02 & 4013074 & 0.20 \\
\hline 412 & PEAT BOGS & 21429312 & 0.27 & 7038320 & 0.36 & 1641119 & 0.08 & 11569666 & 0.59 & 1180207 & 0.06 \\
\hline 511 & WATER COURSES & 1090605 & 0.01 & 335384 & 0.02 & 755220 & 0.04 & - & - & - & - \\
\hline 512 & WATER BODIES & 1219116842 & 15.52 & 288760275 & 14.71 & 231279441 & 11.78 & 373643452 & 19.03 & 325433673 & 16.57 \\
\hline TOTAL & & 7853960679 & 100.00 & 1963490172 & 100.00 & 1963490172 & 100.00 & 1963490167 & 100.00 & 1963490167 & 100.00 \\
\hline
\end{tabular}

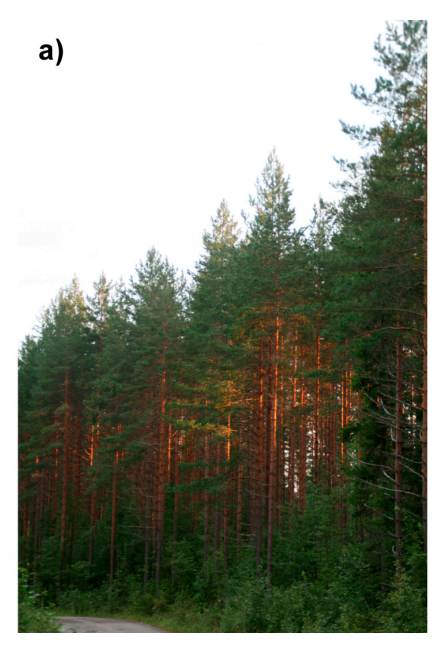

b)

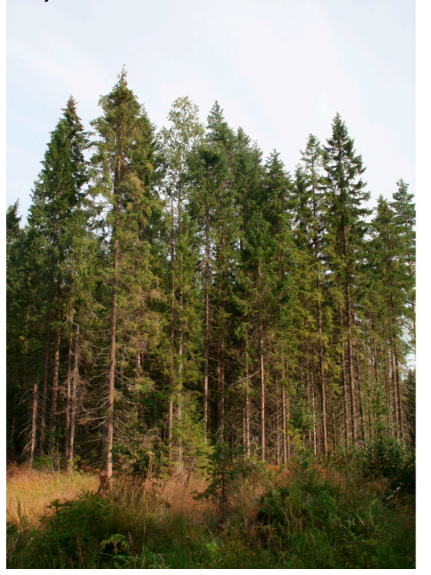

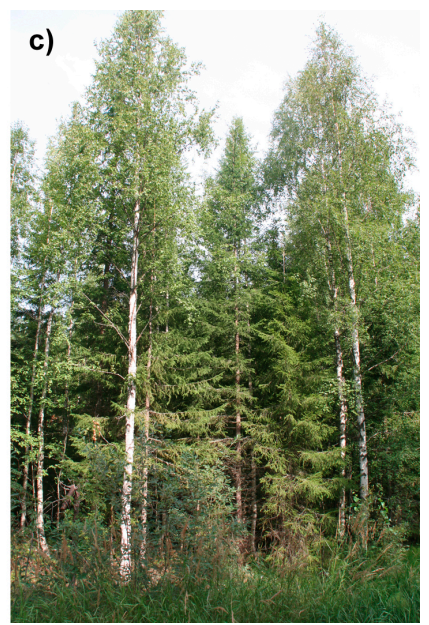

Fig. 6. Densely forested areas within $5 \mathrm{~km}$ of the Hyytiälä site: a) Scots pine designated by the Corine database as "coniferous forest", (b) Spruce, designated by the Corine database as "coniferous forest", and (c) Birch and conifers, designated by the Corine database as "mixed forest."

analyses (not shown) that have crossed St. Petersburg, Russia, a large industrialized area (population $>4.5$ million) located to the southeast of the site. Peaks are also seen in pentane at these times. Such strong peaks in $\mathrm{SO}_{2}$ and pentane are also observed coincident with the biomass burning events 26-30 July. Again in these cases the air was advected over the St Petersburg region suggesting that this is a strong source of $\mathrm{SO}_{2}$ and hydrocarbons to the atmosphere. In the clean air sector from the northwest $\mathrm{SO}_{2}$ was below $200 \mathrm{pmol} \mathrm{mol}^{-1}$. The incidences of high $\mathrm{SO}_{2}$ are also noted in Table 2. On two occasions peaks in n-pentane were observed which did not correlate with $\mathrm{SO}_{2}$ (e.g. 16 July and 6 August). This 


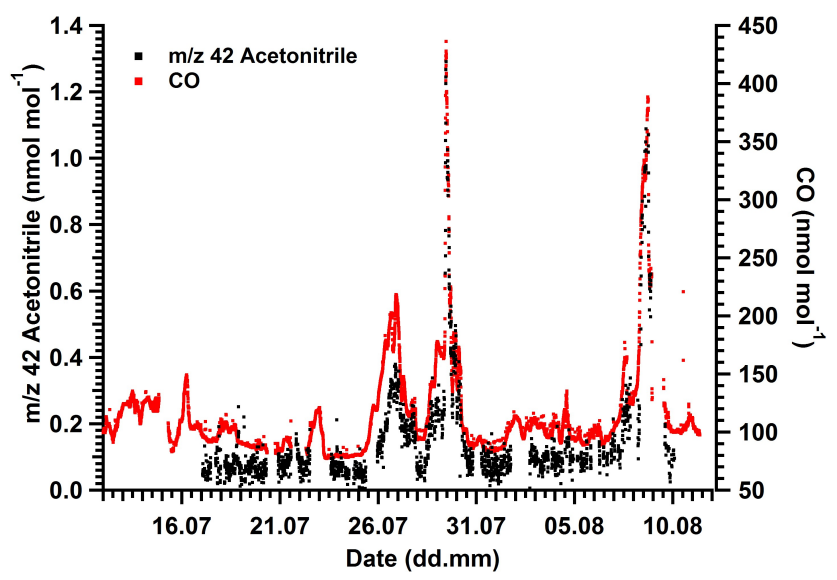

Fig. 7. Acetonitrile $\left(\mathrm{CH}_{3} \mathrm{CN}\right)$ and Carbon monoxide $(\mathrm{CO})$ mixing ratios (5 min averages) for the duration of HUMPPA-COPEC campaign measured at the HUMPPA tower.

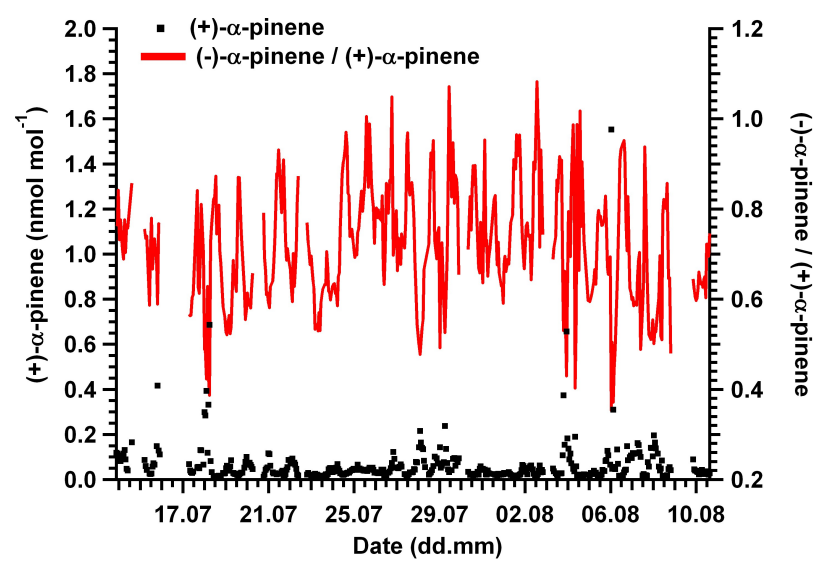

Fig. 8. (+)- $\alpha$-pinene (black) and the ratio of (-) to (+)- $\alpha$-pinene enantiomers (red) are shown. Measurements were made at the HUMPPA tower.

strongly suggests a separate source of the hydrocarbon influenced the site at this time.

\subsection{Particles}

Number concentrations for particles between $3-25 \mathrm{~nm}$ and $3-1000 \mathrm{~nm}$ are shown in Fig. 10a and b. The smaller size range represents the nucleation mode particles whereas the larger size range also includes the Aitken and accumulation modes (termed total particles in Fig. 10). Several elevated events can be seen in the nucleation mode particles. One example, on the 12 of July shows coincident peaks of nucleation mode and total particle concentrations. This is likely a pollution plume advected from southwest of the site possibly Tampere. In contrast a second event, on 23 July, began when total particles $(3-1000 \mathrm{~nm})$ were at a campaign minimum concentration at 06:00 local time, see Fig. 10b. Nucleation

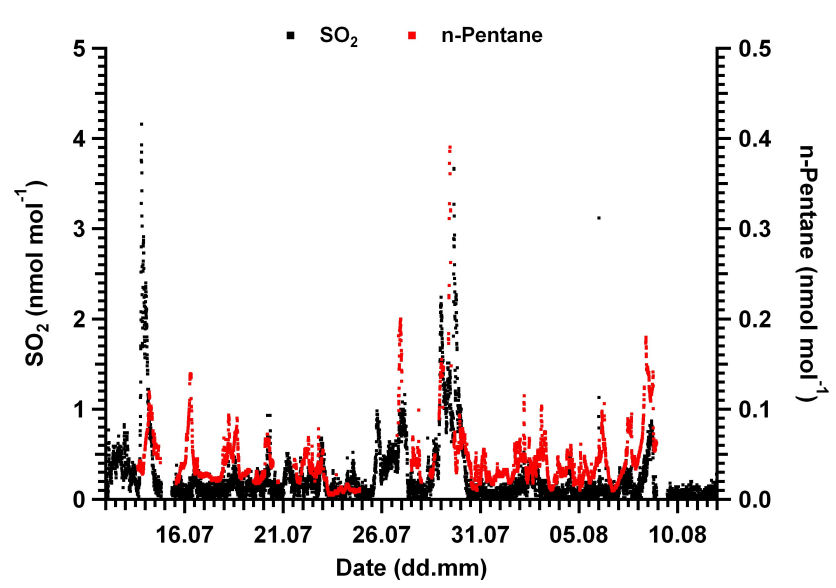

Fig. 9. The mixing ratios of $\mathrm{SO}_{2}$ and n-pentane are plotted for the duration of the HUMPPA-COPEC campaign (plus two days). Measurements taken from the main mast at $16.8 \mathrm{~m}$.

mode particles increased sharply in concentration over the following four hours reaching circa $30000 \mathrm{~cm}^{-3}$. This was the only nucleation event seen at the site during the summer campaign. The generally high levels of total particles from 3-1000 nm observed in the summer campaign provided ample surface area for condensation of semi volatile gas phase species and thus inhibited nucleation. Several "failed events" were noted in which particles were observed to be nucleating but did not grow into the larger size ranges.

\section{Conclusions}

The overall aim of this campaign was to obtain a dataset characteristic of the Boreal forest in summer with which the specific campaign goals (see Sect. 2.1-2.10) can be addressed. During the HUMMPA-COPEC 2010 summer campaign the Hyytiälä site was impacted by periods of extremely high temperature, advected biomass burning emissions, emissions from urban centers in the southwest and occasionally by a nearby sawmill. The latter has the effect of extending the VOC: $\mathrm{NO}_{\mathrm{x}}$ space measured in the campaign and was a valuable test of the $\mathrm{OH}$ reactivity measurements. Fortunately none of these various effects entirely dominated the field study period allowing contrasts between high and low temperatures from clean boreal forest emissions and polluted air masses to be made. Analysis of meteorological sonde data has shown that the boundary layer height, although variable during the campaign, increased typically from less than $200 \mathrm{~m}$ in the early morning to around $1700 \mathrm{~m}$ at the end of the afternoon. During the campaign air was advected mostly from the SW (53.7\%) of the time with smaller influences from the SE (20.7\%) and the NW (10.3\%). In comparison with the previous five years the campaign period in 2010 was more impacted by air from the south (SW and SE) leading to higher ozone and temperature values at the site. A regional 

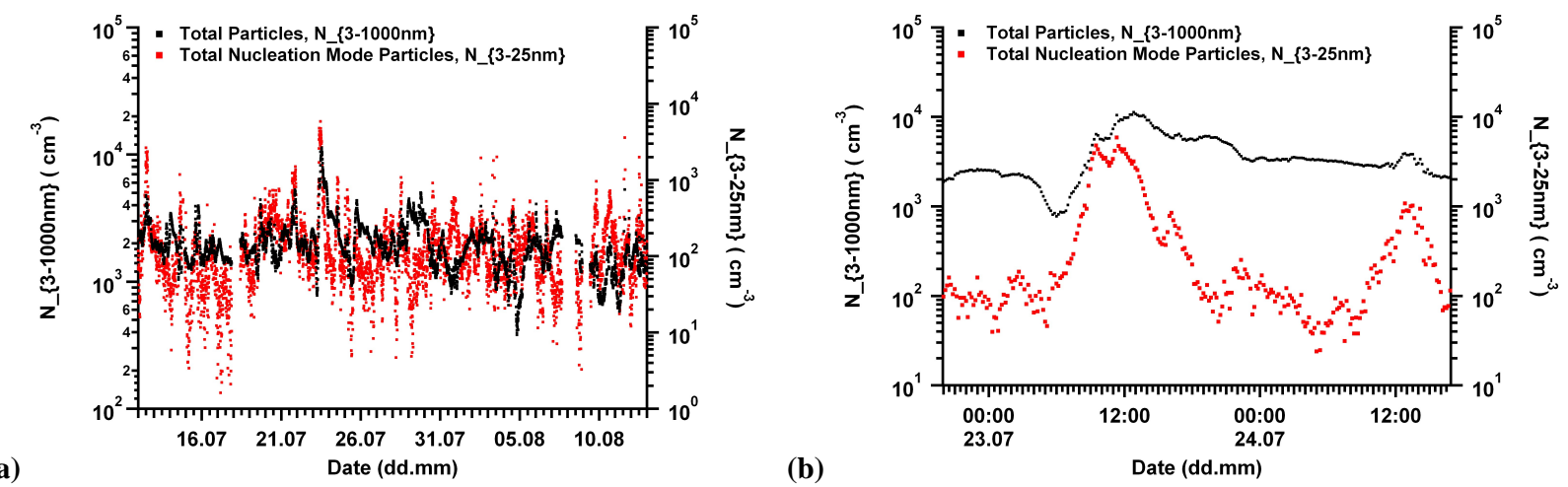

Fig. 10. Number concentrations of particles are plotted for the size range 3-25 nm - (red) and 3-1000 nm (black). Measurements taken from the main mast at $16.8 \mathrm{~m}$.

$50 \mathrm{~km}$ wide surface cover analysis showed that the southern sectors (SW and SE) contain more anthropogenic influence than the NW sector, although coniferous forest was found to dominate in all sectors.

The unusually high temperatures experienced on this campaign are also useful to gauge the response of the Boreal forest to warmer conditions, at least in the short term. For example strong increases in highly reactive mono- and sesqui- terpene emissions were observed during this campaign at higher temperatures, leading to higher $\mathrm{OH}$ reactivities. Temperatures in boreal regions are predicted to rise over this century, and datasets such as HUMPPA-COPEC 2010 can help verify proposed feedbacks to atmospheric properties. It should be noted, however, that over longer climate-scale periods ecological feedbacks as well as larger scale synoptic shifts may dominate.

Acknowledgements. The HUMPPA-COPEC campaign would not have been possible without the excellent support of the Hyytiälä site engineers and staff. Mike Fromm is thanked for information pertaining to the biomass burning events described. The authors gratefully acknowledge the NOAA Air Resources Laboratory (ARL) for the provision of the HYSPLIT transport and dispersion model website (http://www.arl.noaa.gov/ready.php) used in this publication. We also acknowledge the support of the European Community - Research Infrastructure Action under the FP6 "Structuring the European Research Area" Programme. The campaign measurements and analyses were supported by the ERC Grant ATMNUCLE (project no. 227463), Academy of Finland Center of Excellence program (project no. 1118615), The European Integrated project on Aerosol Cloud Climate and Air Quality Interactions EUCAARI (project No 036833-2), the EUSAAR TNA (project No 400586), and the IMECC TA (project No 4006261). Support for Franz Geiger and Carly Ebben from NSF grant \#0856428 is likewise acknowledged. We gratefully acknowledge the help from engineers Rainer Königstedt, Uwe Parchatka, Thomas Klüpfel, Rolf Hofmann, Markus Rudolf, and Gerhard Schuster. FMG thanks the National Science Foundation Atmospheric General Sciences Division for support under grant \# NSF ATM-0533436. CJE acknowledges support from an NSF Graduate Research Fellowship.
The service charges for this open access publication have been covered by the Max Planck Society.

Edited by: M. Kanakidou

\section{References}

Aaltonen, H., Pumpanen, J., Pihlatie, M., Hakola, H., Hellén, H., Kulmala, L., Vesala, T., and Bäck, J.: Boreal pine forest floor biogenic volatile organic compound emissions peak in early summer and autumn, Agr. Forest Meteorol. 151, 682-691, 2011.

Atkinson, R., Baulch, D. L., Cox, R. A., Crowley, J. N., Hampson, R. F., Hynes, R. G., Jenkin, M. E., Rossi, M. J., Troe, J., and IUPAC Subcommittee: Evaluated kinetic and photochemical data for atmospheric chemistry: Volume II - gas phase reactions of organic species, Atmos. Chem. Phys., 6, 3625-4055, doi:10.5194/acp-6-3625-2006, 2006.

Bahadur, R., Uplinger, T., Russell, L. M., Sive, B. C., Cliff, S. C., Millet, D. B., Goldstein, A., and Bates, T. S.: Phenol Groups in Northeastern U. S. Submicron Aerosol Particles Produced from Seawater Sources, Environ. Sci. Technol., 44, 2542-2548, 2010.

Bonn, B., Kulmala, M., Riipinen, I., Sihto, S.-L., and Ruuskanen, T. M.: How biogenic terpenes govern the correlation between sulfuric acid concentrations and new particle formation, J. Geophys. Res. 113, D12209, doi:10.1029/2007JD009327, 2008.

Boy, M., Sogachev, A., Lauros, J., Zhou, L., Guenther, A., and Smolander, S.: SOSA - a new model to simulate the concentrations of organic vapours and sulphuric acid inside the ABL Part 1: Model description and initial evaluation, Atmos. Chem. Phys., 11, 43-51, doi:10.5194/acp-11-43-2011, 2011.

Butler, T. M., Taraborrelli, D., Briihl, C., Fischer, H., Harder, H.,Martinez, M., Williams, J., Lawrence, M. G., and Lelieveld, J.: Improved simulation of isoprene oxidation chemistry with the ECHAM5/MESSy chemistry-climate model: lessons from the GABRIEL airborne field campaign, Atmos. Chern. Phys., 8, 4529-4546, doi:10.5194/acp-8-4529-2008, 2008.

Carslaw, K. S., Boucher, O., Spracklen, D. V., Mann, G. W., Rae, J. G. L., Woodward, S., and Kulmala, M.: A review of natural aerosol interactions and feedbacks within the Earth system, 
Atmos. Chem. Phys., 10, 1701-1737, doi:10.5194/acp-10-17012010, 2010

Coffman, D. J. and Hegg, D. A.: A preliminary study of the effect of ammonia on particle nucleation in the marine boundary layer, J. Geophys. Res. 100, 7147-7160, 1995.

Draxler, R. R. and Rolph, G. D.: HYSPLIT (HYbrid Single-Particle Lagrangian Integrated Trajectory) Model access via NOAA ARL READY Website (http://ready.arl.noaa.gov/HYSPLIT. php), NOAA Air Resources Laboratory, Silver Spring, MD, 2011.

Ebben, C. J., Martinez, I. S., Shrestha, M., Buchbinder, A. M., Corrigan, A. L., Guenther, A., Karl, T., Petäjä, T., Song, W. W., Zorn, S. R., Artaxo, P., Kulmala, M., Martin, S. T., Russell, L. M., Williams, J., and Geiger, F. M.: Contrasting organic aerosol particles from boreal and tropical forests during HUMPPA-COPEC-2010 and AMAZE-08 using coherent vibrational spectroscopy, Atmos. Chem. Phys. Discuss., 11, 1693316966, doi:10.5194/acpd-11-16933-2011, 2011.

Eerdekens, G., Yassaa, N., Sinha, V., Aalto, P. P., Aufmhoff, H., Arnold, F., Fiedler, V., Kulmala, M., and Williams, J.: VOC measurements within a boreal forest during spring 2005: on the occurrence of elevated monoterpene concentrations during night time intense particle concentration events, Atmos. Chem. Phys., 9, 8331-8350, doi:10.5194/acp-9-8331-2009, 2009.

EEA: Technical and Methodological Guide for Updating CORINE Land Cover Data Base. European Environment Agency, EUR 17288 EN, 1997.

Food and Agriculture Organsation (FAO): Global forest resources assessment, FAO Forestry paper 163, ISBN 978-92-5-106654-6, 2010.

Fuchs, H., Brauers, T., Dorn, H.-P., Harder, H., Häseler, R., Hofzumahaus, A., Holland, F., Kanaya, Y., Kajii, Y., Kubistin, D., Lou, S., Martinez, M., Miyamoto, K., Nishida, S., Rudolf, M., Schlosser, E., Wahner, A., Yoshino, A., and Schurath, U.: Technical Note: Formal blind intercomparison of HO2 measurements in the atmosphere simulation chamber SAPHIR during the HOxComp campaign, Atmos. Chem. Phys., 10, 12233-12250, doi:10.5194/acp-10-12233-2010, 2010.

Ganzeveld, L., Eerdekens, G., Feig, G., Fischer, H., Harder, H., Knigstedt, R., Kubistin, D., Martinez, M., Meixner, F. X., Scheeren, H. A., Sinha, V., Taraborrelli, D., Williams, J., VilàGuerau de Arellano, J., and Lelieveld, J.: Surface and boundary layer exchanges of volatile organic compounds, nitrogen oxides and ozone during the GABRIEL campaign, Atmos. Chem. Phys., 8, 6223-6243, doi:10.5194/acp-8-6223-2008, 2008.

Goldstein, A. H. and Galbally, I. E.: Known and unexplored organic constituents in the Earths atmosphere, Environ. Sci. Technol., 41, 15141521, doi:10.1021/es072476p, 2007.

Haapanala, S., Rinne, J., Hakola, H., Hellén, H., Laakso, L., Lihavainen, H., Janson, R., O'Dowd, C., and Kulmala, M.: Boundary layer concentrations and landscape scale emissions of volatile organic compounds in early spring, Atmos. Chem. Phys., 7, 1869-1878, doi:10.5194/acp-7-1869-2007, 2007.

Hakola, H., Rinne J., and Laurila, T.: Hydrocarbon emission rates of tea-leafed willow (Salix phylicifolia), Silver birch (Betula pendula) and European aspen (Populus tremula), Atmos. Environ., 32, 1825-1833, 1998.

Hakola, H., Laurila, T., Rinne, J., and Puhto, K.: The ambient concentrations of biogenic hydrocarbons at a northern European, bo- real site, Atmos. Environ., 34, 4971-4982, 2000.

Hakola, H., Tarvainen, V., Laurila, T., Hiltunen, V., Hellen, H., and Keronen, P.: Seasonal variation of VOC concentrations above a boreal coniferous forest, Atmos. Environ., 37, 1623-1634, 2003.

Hakola, H., Tarvainen, V., Bäck, J., Ranta, H., Bonn, B., Rinne, J., and Kulmala, M.: Seasonal variation of mono- and sesquiterpene emission rates of Scots pine, Biogeosci., 3, 93-101, 2006.

Hallquist, M., Wenger, J. C., Baltensperger, U., Rudich, Y., Simpson, D., Claeys, M., Dommen, J., Donahue, N. M., George, C., Goldstein, A. H., Hamilton, J. F., Herrmann, H., Hoff- mann, T., Iinuma, Y., Jang, M., Jenkin, M. E., Jimenez, J. L., Kiendler-Scharr, A., Maenhaut, W., McFiggans, G., Mentel, Th. F., Monod, A., Prevot, A. S. H., Seinfeld, J. H., Surratt, J. D., Szmigielski, R., and Wildt, J.: The formation, properties and impact of secondary organic aerosol: current and emerging issues, Atmos. Chem. Phys., 9, 51555236, HYPERLINK http://dx.doi.org/10.5194/acp-9-51552009 doi:10.5194/acp-9-5155-2009, 2009.

Hari, P. and Kulmala, M.: Station for measuring ecosystematmosphere relations (SMEAR II), Boreal Env. Res., 10, 5, 315322, 2005.

Hewitt, C. N., Lee, J. D., MacKenzie, A. R., Barkley, M. P., Carslaw, N., Carver, G. D., Chappell, N. A., Coe, H., Collier, C., Commane, R., Davies, F., Davison, B., DiCarlo, P., Di Marco, C. F., Dorsey, J. R., Edwards, P. M., Evans, M. J., Fowler, D., Furneaux, K. L., Gallagher, M., Guenther, A., Heard, D. E., Helfter, C., Hopkins, J., Ingham, T., Irwin, M., Jones, C., Karunaharan, A., Langford, B., Lewis, A. C., Lim, S. F., MacDonald, S. M., Mahajan, A. S., Malpass, S., McFiggans, G., Mills, G., Misztal, P., Moller, S., Monks, P. S., Nemitz, E., Nicolas-Perea, V., Oetjen, H., Oram, D. E., Palmer, P. I., Phillips, G. J., Pike, R., Plane, J. M. C., Pugh, T., Pyle, J. A., Reeves, C. E., Robinson, N. H., Stewart, D., Stone, D., Whalley, L. K., and Yin, X.: Overview: oxidant and particle photochemical processes above a south-east Asian tropical rainforest (the OP3 project): introduction, rationale, location characteristics and tools, Atmos. Chem. Phys., 10, 169-199, doi:10.5194/acp-10-169-2010, 2010.

Janson, R. and de Serves, C.: Acetone and monoterpene emissions from the boreal forest in northern europe, Atmos. Environ., 35, 4629-4637, 2001.

Janson, R., de Serves, C., and Romero, R.: Emission of isoprene and carbonyl compounds from a boreal forest and wetland in Sweden, Agric. Forest Meteorol., 98-99, 671681, 1999.

Junninen, H., Lauri, A., Keronen, P., Aalto, P., Hiltunen, V., Hari, P., and Kulmala, M.: Smart-SMEAR: on-line data exploration and visualization tool for SMEAR stations, Boreal Env. Res., 14, 447-457, 2009.

Kanakidou, M., Seinfeld, J. H., Pandis, S. N., Barnes, I., Dentener, F. J., Facchini, M. C., Van Dingenen, R., Ervens, B., Nenes, A., Nielsen, C. J., Swietlicki, E., Putaud, J. P., Balkanski, Y., Fuzzi, S., Horth, J., Moortgat, G. K., Winterhalter, R., Myhre, C. E. L., Tsigaridis, K., Vignati, E., Stephanou, E. G., and Wilson, J.: Organic aerosol and global climate modelling: a review, Atmos. Chem. Phys., 5, 10531123, doi:10.5194/acp-5-1053-2005, 2005.

Kulmala, M. and Kerminen V.-M.: On the growth of atmospheric nanoparticles, Atmos. Res., 90, 132-150, 2008.

Kulmala, M., Hameri, K., Aalto, P. P., Makela, J. M., Pirjola, L.,Nilsson, E. D., Buzorius, G., Rannik, U., Dal Maso, M., 
Seidl,W., Hoffman, T., Janson, R., Hansson, H. C., Viisanen, Y., Laaksonen,A., and O'Dowd, C. D.: Overview of the international project on biogenic aerosol formation in the boreal forest (BIOFOR), Tellus B, 53, 324-343, 2001.

Kulmala, M., Vehkamäki, H., Petäjä, T., Dal Maso, M., Lauri, A., Kerminen, V. M., Birmili, W., and McMurry, P.H.: Formation and growth rates of ultrafine atmospheric particles: a review of observations, J. Aerosol. Sci., 35, 143-176, doi:10.1016/j.jaerosci.2003.10.003, 2004.

Kulmala, M., Lehtinen, K. E. J., and Laaksonen, A.: Cluster activation theory as an explanation of the linear dependence between formation rate of $3 \mathrm{~nm}$ particles and sulphuric acid concentration, Atmos. Chem. Phys., 6, 787-793, doi:10.5194/acp-6-787-2006, 2006.

Kulmala, M., Riipinen, I., Sipilä, M., Manninen, H. E., Petäjä, T., Junninen, H., Dal Maso, M., Mordas, G., Mirme, A., Vana, M., Hirsikko, A., Laakso, L., Harrison, R. M.,Hanson, I., Leung, C., Lehtinen, K. E. J., and Kerminen, V.-M.: Towards Direct Measurement of Atmospheric Nucleation, Science, 318, 89-92, 2007.

Kurten, T., Kulmala, M., Dal Maso, M., Suni, T., Reissell, A.,Vehkamäki, H., Hari, P., Laaksonen, A., Viisanen, Y., and Vesala,T.: Estimation of different forest-related contributions to the radiative balance using observations in southern Finland, Boreal Env. Res., 8, 275-285, 2003.

Lelieveld, J., Butler, T. M., Crowley, J.N. Dillon, T.J. Fischer, H., Ganzeveld, L., Harder, H., Lawrence, M., Martinez, M., Taraborrelli D., and Williams, J.: Atmospheric oxidation capacity sustained by a tropical forest, Nature, 452, 737-740, 2008.

Lobert, J. M., Scharffe, D. H., Hao, W. M., and Crutzen, P. J.:Importance of biomass burning in the atmospheric budgets ofnitrogen-containing gases, Nature, 346, 552-554, 1990.

Lovejoy, E. R., Curtius, J., and Froyd, K. D.: Atmospheric ioninduced nucleation of sulfuric acid and water, J. Geophys. Res., 109, D08204, doi:10.1029/2003JD004460, 2004.

Martinez, M., Harder, H., Kubistin, D., Rudolf, M., Bozem, H., Eerdekens, G., Fischer, H., Klüpfel, T., Gurk, C., Königsstedt, R., Parchatka, U., Schiller, C. L., Stickler, A., Williams, J., and Lelieveld, J.: Hydroxyl radicals in the tropical troposphere over the Suriname rainforest: airborne measurements, Atmos. Chem. Phys., 10, 3759-3773, doi:10.5194/acp-10-3759-2010, 2010.

McMurry P. H. and Friedlander, S. K.: New particle formation in the presence of aerosol, Atmos. Environ., 13, 1635-1651, 1979.

Napari, I., Noppel, M., Vehkamäki, H., and Kulmala, M.:Parameterization of ternary nucleation rates for $\mathrm{H}_{2} \mathrm{SO}_{4}-\mathrm{NH}_{3}-\mathrm{H}_{2} \mathrm{O}$ vapors, J. Geophys. Res., 107, 4381, doi:10.1029/2002JD002132, 2002.

Noppel, M., Vehkamäki, H., and Kulmala, M.: An improved model for hydrate formation in sulfuric acid-water nucleation, J. Chem. Phys. 116, 218-228, 2002.

Nölscher, A., Williams, J., Sinha, V. and Lelieveld, J.: OH reactivity in and above a Boreal forest, HUMPPA-COPEC 2010 special section, Atmos. Chem. Phys. Discuss., in preparation, 2011a.

Nölscher, A., Sinha, V., Williams J.: Using a GC-PID detector for ambient $\mathrm{OH}$ reactivity measurements, Atmos. Meas. Tech. Discuss., in preparation, $2011 \mathrm{~b}$.

Novelli, A., Hens, K., Rudolf, M., Martinez, M., Harder, H., Petäjä, T., Kulmala, M., and Lelieveld, J.: A field comparison of LIF and CIMs techniques for $\mathrm{OH}$ measurement in a boreal forest, in preparation, Atmos. Chem. Phys. Discuss., 2011.

Paulot, F., Crounse, J. D., Kjaergaard, H. G., Kürten, A., St. Clair, J. M., Seinfeld,. J. H., and Wennberg, P. O.: Unexpected Epoxide Formation in the Gas-Phase Photooxidation of Isoprene, Science, 325, 730-733, doi:10.1126/science.1172910, 2009.

Peeters, J., Nguyen, T. L., and Vereecken, L.: $\mathrm{HO}_{\mathrm{x}}$ radical regeneration in the oxidation of isoprene, Phys. Chem. Chem. Phys., 11, 5935, doi:10.1039/b908511d, 2009.

Petäjä, T., Mauldin, III, R. L., Kosciuch, E., McGrath, J., Nieminen, T., Paasonen, P., Boy, M., Adamov, A., Kotiaho, T., and Kulmala, M.: Sulfuric acid and $\mathrm{OH}$ concentrations in a boreal forest site, Atmos. Chem. Phys., 9, 7435-7448, doi:10.5194/acp9-7435-2009, 2009

Pugh, T. A. M., MacKenzie, A. R., Langford, B., Nemitz, E., Misztal, P. K., and Hewitt, C. N.: The influence of small-scale variations in isoprene concentrations on atmospheric chemistry over a tropical rainforest, Atmos. Chem. Phys., 11, 4121-4134, doi:10.5194/acp-11-4121-2011, 2011.

Räisänen, T., Ryyppö, A., and Kellomäki, S.: Monoterpene emission of a boreal Scots pine (Pinus sylvestris L.) forest, Agr. For. Meteorol., 149, 808-819, 2009.

Ren, X., Harder, H., Martinez, M., Faloona, I. C., Tan, D., Lesher, R. L., Di Carlo, P., Simpas J., and Brune, W. H.: Interference Testing for Atmospheric $\mathrm{HO}_{\mathrm{x}}$ Measurements by Laser-induced Fluorescence, J. Atmos. Chem. 47, 2, 169-190, doi:10.1023/B:JOCH.0000021037.46866.81., 2003.

Rinne, J., Ruuskanen, T. M., Reissell, A., Taipale, R., Hakola, H., and Kulmala, M.: On-line PTR-MS measurements of atmospheric concentrations of volatile organic compounds in a European boreal forest ecosystem, Boreal Environ. Res., 10, 425-436, 2005.

Rinne, J., Taipale, R., Markkanen, T., Ruuskanen, T. M., Hellén, H., Kajos, M. K., Vesala, T., and Kulmala, M.: Hydrocarbon fluxes above a Scots pine forest canopy: measurements and modeling, Atmos. Chem. Phys., 7, 3361-3372, doi:10.5194/acp-73361-2007, 2007.

Rolph, G. D.: Real-time Environmental Applications and Display sYstem (READY) Website (http://ready.arl.noaa.gov). NOAA Air Resources Laboratory, Silver Spring, MD, 2010.

Russell, L. M., Takahama, S., Liu, S., Hawkins, L. N., Covert, D. S., Quinn, P. K., Bates, T. S.: Oxygenated fraction and mass of organic aerosol from direct emission and atmospheric processing measured on the R/V Ronald Brown during TEXAQS/GoMACCS 2006, J. Geophy. Res. Atmos., 114, D00F05, doi:10.1029/2008JD011275, 2009.

Russell, L.M., Bahadur, R., and Ziemann, P. J.: Identifying organic aerosol sources by comparing functional group composition in chamber and atmospheric particles, Proc. Nat. Acad. Sci., 108, 9, 3516-3521 doi/10.1073/pnas.1006461108, 2011.

Schlosser, E., Brauers, T., Dorn, H.-P., Fuchs, H., Häseler, R., Hofzumahaus, A., Holland, F., Wahner, A., Kanaya, Y., Kajii, Y., Miyamoto, K., Nishida, S., Watanabe, K., Yoshino, A., Kubistin, D., Martinez, M., Rudolf, M., Harder, H., Berresheim, H., Elste, T., Plass-Dlmer, C., Stange, G., and Schurath, U.: Technical Note: Formal blind intercomparison of $\mathrm{OH}$ measurements: results from the international campaign HOxComp, Atmos. Chem Phys., 9, 7923-7948, doi:10.5194/acp-9-7923-2009, 2009.

Schwartz, R. E., Russell, L. M., Sjostedt, S. J., Vlasenko, A., Slowik, J. G., Abbatt, J. P. D., Macdonald, A. M., Li, S. M., 
Liggio, J., Toom-Sauntry, D., and Leaitch, W. R.: Biogenic oxidized organic functional groups in aerosol particles from a mountain forest site and their similarities to laboratory chamber products, Atmos. Chem. Phys., 10, 5075-5088, doi:10.5194/acp-105075-2010, 2010.

Sihto, S.-L., Mikkilä, J., Vanhanen, J., Ehn, M., Liao, L., Lehtipalo, K., Aalto, P. P., Duplissy, J., Petäjä, T., Kerminen, V.-M., Boy, M., and Kulmala, M.: Seasonal variation of CCN concentrations and aerosol activation properties in boreal forest, Atmos. Chem. Phys. Discuss., 10, 28231-28272, doi:10.5194/acpd-10-282312010, 2010.

Sinha, V., Williams, J., Crowley, J. N., and Lelieveld, J.: The Comparative Reactivity Method - a new tool to measure total $\mathrm{OH}$ Reactivity in ambient air, Atmos. Chem. Phys., 8, 2213-2227, doi:10.5194/acp-8-2213-2008, 2008.

Sinha, V., Williams, J., Lelieveld, J. Ruuskanen, T. M., Kajos, M. K. Patokoski, J., Hellen, H., Hakola, H., Mogensen, D., Boy, M., Rinne, J., and Kulmala, M.: OH Reactivity Measurements within a Boreal Forest: Evidence for Unknown Reactive Emissions, Env. Sci. Technol., 44, 6614-6620, 2010.

Spracklen, D., Bonn, B. and Carlsaw, K. S.: Boreal forests, aerosols and the impacts on clouds and climate, Phil. Trans. R. Soc. A., 366, 4613-4626, 2008.

Stokes, G. Y., Chen, E. H., Buchbinder, A. M., Paxton, W. F., Keeley, A., and Geiger, F. M.: Atmospheric heterogeneous stereochemistry, J. Amer. Chem. Soc. 131, 13733-13737, 2009.

Stull, R. B.: An Introduction to Boundary Layer Meteorology, Kluwer Academic Publishers, Dordrecht, The Netherlands, 1988.

Takahama, S., Schwartz, R. E., Russell, L. M., Macdonald, A. M., Sharma, S., and Leaitch, W. R.: Organic functional groups in aerosol particles from burning and non-burning forest emissions at a high-elevation mountain site, Atmos. Chem. Phys., 11, 6367-6386, doi:10.5194/acp-11-6367-2011, 2011.

Tarvainen, V., Hakola, H., Hellén, H., Bäck, J., Hari, P., and Kulmala, M.: Temperature and light dependence of the VOC emissions of Scots pine, Atmos. Chem. Phys., 5, 989-998, 2005, http://www.atmos-chem-phys.net/5/989/2005/.

Tunved, P., Hansson, H.-C., Kulmala, M., Aalto, P., Viisanen, Y., Karlsson, H., Kristensson, A., Swietlicki, E., Dal Maso, M., Ström, J., and Komppula, M.: One year boundary layer aerosol size distribution data from five nordic background stations, Atmos. Chem. Phys., 3, 2183-2205, doi:10.5194/acp-3-2183-2003, 2003.
Tunved, P., Hansson, H.-C., Kerminen, V.-M., Ström, J., Dal Maso, M., Lihavainen, H., Viisanen, Y., Aalto, P. P., Komppula, M., and Kulmala, M.: High natural aerosol loading over boreal forests, Science, 312, 261-263, 2006.

Tunved, P., Ström, J., Kulmala, M., Kerminen, V.-M., Dal Maso, M., Svenningson, B., Lunder, C., and Hansson, H.C.: The natural aerosol over Northern Europe and its relation to anthropogenic emissions - Implications of important climate feedbacks, Tellus B, 60, 473-484, doi:10.1111/j.16000889.2008.00363.x, 2008.

Vehkamäki, H., Kulmala, M., Napari, I., Lehtinen, K. E. J., Timmreck, C., Noppel, M. and Laaksonen A.: An improved parameterization for sulfuric acid-water nucleation rates for tropospheric and stratospheric conditions, J. Geophys. Res., 107, 4622, doi:10.1029/2002JD002184, 2002.

Vilà-Guerau de Arellano, J., Patton, E. G., Karl, T., Van den Dries, K., Barth, M. C., and Orlando, J. J.: The role of boundary layer dynamics on the diurnal evolution of isoprene and the hydroxyl radical over tropical forests, J. Geophys. Res. Atmos., 116, D07304, doi:10.1029/2010JD014857, 2011.

Williams, J., Yassaa, N., Bartenbach, S., and Lelieveld, J.: Mirror image hydrocarbons from Tropical and Boreal forests, Atmos. Chem. Phys., 7, 973-980, doi:10.5194/acp-7-973-2007, 2007.

Yassaa, N. and Williams, J.: Analysis of enantiomeric and nonenantiomeric monoterpenes in plant emissions using portable dynamic air sampling/solid-phase microextraction (PDAS-SPME) and chiral gas chromatography/mass spectrometry Atmos. Environ., 39, 4875-4884, 2005.

Yassaa, N. and Williams, J.: Enantiomeric monoterpene emissions from natural and damaged Scots pine in a boreal coniferous forest measured using solid-phase microextraction and gas chromatography/ mass spectrometry, J. Chromatogr. A, 1141, 138144, 2007.

Yassaa, N. Williams, J., Bäck, J., Kulmala, M., and Lelieveld, $\mathrm{J} .:$ Emissions of enantiomeric monoterpenes and sesquiterpenes measured from cuvettes, HUMPPA-COPEC 2010 special section, Atmos. Chem. Phys. Discuss., in preparation, 2011. 